\title{
The effectiveness of the Peyton's 4-step teaching approach on skill acquisition of procedures in health professions education: A systematic review and meta-analysis with integrated meta-regression
}

\author{
Katia Giacomino ${ }^{\text {Equal first author, } 1}$, Rahel Caliesch ${ }^{1}$, Karl Martin Sattelmayer ${ }^{\text {Corresp. Equal first author, } 1}$ \\ ${ }^{1}$ School of Health Sciences, University of Applied Sciences and Arts Western Switzerland Valais (HES-SO Valais-Wallis), Leukerbad, Valais, Switzerland \\ Corresponding Author: Karl Martin Sattelmayer \\ Email address: martin.sattelmayer@hevs.ch
}

Background. Acquisition of procedures is an important element in health professions education. Traditionally procedures are taught using a "see one - do one" approach. That is a teacher demonstrates and describes a procedure and afterwards the students practice the procedure. A more recent teaching approach for the acquisition of procedural skills was presented by Walker and Peyton. Peyton's teaching approach is a stepwise teaching approach and consists of the following four steps: demonstration, deconstruction, comprehension and performance. The aims of this study were i) to systematically evaluate the effectiveness of Peyton's 4-step teaching approach on the acquisition of procedural skills in health professions education and ii) to evaluate whether studies with fewer students per teacher showed a larger between group difference than studies with more students per teacher.Methods. We searched in Medline, Psyclnfo, Embase and ERIC for eligible studies. Records were screened by two independent reviewers. A random effects meta-analysis was performed to evaluate skill acquisition and time needed to perform the procedures at post-acquisition and retention tests. A meta-regression was used to explore the effect of the number of students per teacher on the estimated effect of the educational interventions.Results. An effect size of 0.45 SMD $(95 \% \mathrm{Cl}: 0.15 ; 0.75)$ at post-acquisition and 0.7 SMD $(95 \% \mathrm{Cl}:-0.09 ; 1.49)$ at retention testing were in favour of Peyton's teaching approach for skill acquisition. The groups using Peyton's teaching approach needed considerably less time to perform the procedure at post-acquisition (SMD: $-0.8 ; 95 \% \mathrm{Cl}$ : -2.13 to 1.62 ) and retention (SMD: $-2.65 ; 95 \% \mathrm{Cl}:-7.77$ to 2.47 ) testing. The effectiveness of Peyton's teaching approach was less clear in subgroup analyses using peer teachers. Meta-regression showed that the number of students per teacher was an important moderator variable.Conclusion. Peyton's teaching approach is an effective teaching approach for skill acquisition of procedural skills in health professions education. When peer students or student tutors are used as teachers the effectiveness of Peyton's 
teaching approach is less clear. Peyton's teaching approach is more effective when small groups with few students per teacher are used. 
1 The effectiveness of the Peyton's 4-step teaching

2 approach on skill acquisition of procedures in health

3 professions education: a systematic review and

4 meta-analysis with integrated meta-regression

5

6 Katia Giacomino ${ }^{1}$, Rahel Caliesch ${ }^{1}$, Karl Martin Sattelmayer ${ }^{1}$

7

$8{ }^{1}$ School of Health Sciences, University of Applied Sciences and Arts Western Switzerland

9 Valais (HES-SO Valais-Wallis), Leukerbad, Switzerland

10

11

12 Corresponding Author:

13

14 Karl Martin Sattelmayer

15 Rathausstr. 8, Leukerbad, Valais, 3954, Switzerland

16 Email address: martin.sattelmayer@hevs.ch 


\section{Abstract}

18 Background. Acquisition of procedures is an important element in health professions education. Traditionally procedures are taught using a "see one - do one" approach. That is a teacher demonstrates and describes a procedure and afterwards the students practice the procedure. A more recent teaching approach for the acquisition of procedural skills was presented by Walker and Peyton. Peyton's teaching approach is a stepwise teaching approach and consists of the following four steps: demonstration, deconstruction, comprehension and performance. The aims of this study were i) to systematically evaluate the effectiveness of Peyton's 4-step teaching approach on the acquisition of procedural skills in health professions education and ii) to evaluate whether studies with fewer students per teacher showed a larger between group difference than studies with more students per teacher.

Methods. We searched in Medline, PsycInfo, Embase and ERIC for eligible studies. Records were screened by two independent reviewers. A random effects meta-analysis was performed to evaluate skill acquisition and time needed to perform the procedures at post-acquisition and retention tests. A meta-regression was used to explore the effect of the number of students per teacher on the estimated effect of the educational interventions.

Results. An effect size of 0.45 SMD $(95 \% \mathrm{CI}$ : $0.15 ; 0.75)$ at post-acquisition and $0.7 \mathrm{SMD}$ $(95 \% \mathrm{CI}:-0.09 ; 1.49)$ at retention testing were in favour of Peyton's teaching approach for skill acquisition. The groups using Peyton's teaching approach needed considerably less time to perform the procedure at post-acquisition (SMD: -0.8 ; 95\% $\mathrm{CI}$ : -2.13 to 1.62 ) and retention (SMD: -2.65 ; 95\%CI: -7.77 to 2.47 ) testing. The effectiveness of Peyton's teaching approach was less clear in subgroup analyses using peer teachers. Meta-regression showed that the number of students per teacher was an important moderator variable. procedural skills in health professions education. When peer students or student tutors are used as teachers the effectiveness of Peyton's teaching approach is less clear. Peyton's teaching approach is more effective when small groups with few students per teacher are used. 


\section{Introduction}

58 Acquisition of procedures is an important element in health professions education (Grantcharov \& Reznick 2008). Historically, the study of the acquisition of procedural skills was primarily in the field of medical and especially surgical education. However, other health professions such as nursing and physiotherapy education have developed assessment and teaching approaches for these skills as well (Oermann et al. 2016; Sattelmayer et al. 2017). Defining procedural skills is challenging. Michels et al. (2012) reported that there is considerable overlap between the terms clinical skills, psychmotor skills and procedural skills.

Traditionally procedures are taught using a "see one - do one" approach. This means that a teacher demonstrates and describes a procedure and afterwards the students are asked to practice the procedure. This is referred to as Halsted's teaching approach, which is based on the surgeon William Steward Halsted (1904). The approach was used as an element to redesign surgical education and create a new system for training young surgeons (Cameron 1997). Although the "see one - do one" approach is often used in the training of health professionals, there is criticism of this approach. First, the approach has been used for decades and does not adhere to recent principles of adult learning such as active learner involvement (McLeod et al. 2001). Furthermore, it was reported that patient safety might be at risk because complex procedures cannot be acquired after a single observation and practice trial (Kotsis \& Chung 2013). Given the diversity of existing procedures today, others argue that the teaching approach should be modified to "see many, learn from the result and do many" (Rohrich 2006). A more recent teaching approach for the acquisition of procedural skills was presented by Walker and Peyton (1998). Peyton's teaching approach is a stepwise teaching approach and consists of the following four steps: i) step 1 refers to the demonstration of the whole procedure in real time ("demonstration"); ii) in step 2 the teacher repeats the demonstration but this time all procedural sub-steps are described (“deconstruction"); iii) during step 3 the student talks the teacher through the procedure. The teacher performs the procedure under the guidance of the student ("comprehension") and iv) in step 4 the students carry out the procedure on their own 84 initiative ("performance"). A similar stepwise teaching approach was presented by George (American College of Surgeons 1997) and later published by George and Doto (2001). Originally, it was developed as an educational technique to support the American College of Surgeon's Advanced Trauma Life Support course. In contrast to Peyton's teaching approach George and Doto used five steps. Within Peyton's teaching approach two of the five steps are collated into a single step. George and Doto based their teaching approach on Simpson's taxonomy of the psychomotor domain (Simpson 1966). Especially the third step seems to be important in Peyton's teaching approach and was assumed to be beneficial for skill acquisition. The process of guiding the teacher through the procedure requires the student to remember and think about the first two steps before giving the teacher the necessary information (Gradl-Dietsch et al. 2016). This process could help students to organise their thoughts and support student-centred learning (Lom 2012). Similarly, Balafoutas and 
97 colleagues (2019) argue that students need to manipulate the information stored in their working 98 memory based on the information provided in the first two steps. This could support the transfer 99 of relevant information into the long-term memory. Other authors have argued that recognising 100 the effects of the instructions on the performance could be a valuable source of feedback and 101 might improve metacognitive skills (Herrmann-Werner et al. 2013). In addition, Rossettini et al.

102 (2017) mentioned that Peyton's third step involves elements of mental practice. That is, the 103 students have the possibility to develop a mental representation of the movement in absence of 104 an active movement. There exists evidence that mental practice is effective for skill acquisition 105 of procedures in health professions education (Sattelmayer et al. 2016).

106 Besides the third step, the fourth step is also of educational importance as in this step the teacher 107 provides feedback to the learner. A systematic review by Issenberg reported that the opportunity 108 to provide feedback is a key component for effective skill acquisition in simulation-based 109 medical education (Issenberg et al. 2005). In addition, the fourth step is also supported by 110 Bandura's scaffolding theory (Schunk 2012).

111 One of the strengths of Peyton's teaching approach is that it can be effectively combined with

112 other instructional design strategies, which allows the simultaneous delivery of theoretical

113 concepts along with complex procedural skills. For example, Tambi et al. (2018) and colleagues

114 combined Gagne's instructional model (Gagne et al. 2005) with Peyton's teaching approach to

115 design a bioinformatics lesson plan for medical students and $\mathrm{Ng}$ (2014) combined both teaching

116 approaches for slit-lamp teaching.

117 However, one could assume that the step-by-step approach would require considerably more

118 time for teaching. The traditional teaching approach consist typically of two steps (demonstration

119 and practice). The additional two steps might be assumed to be time-consuming. However, in

120 contrast to this, several authors have reported that not more time was required using Peyton's 121 approach (Krautter et al. 2011; Rossettini et al. 2017).

122 Several randomised controlled trials have evaluated the effectiveness of Peyton's teaching 123 approach. The results of these studies are not always consistent. Some trials have reported 124 findings in favour of Peyton's approach (e.g. Balafoutas et al. 2019; Rossettini et al. 2017).

125 Rossettini et al. (2017) showed that acquisition of a cervical mobilisation technique was

126 considerable higher in the Peyton group compared to a standard teaching group. In contrast, Orde 127 et al. (2010) have reported that Peyton's teaching approach showed only minor differences on 128 skill acquisition regarding insertion of a laryngeal mask airway at post-acquisition and retention 129 testing compared to a traditional teaching approach.

130 Originally Peyton's teaching approach was designed for a student-teacher ratio of 1:1 (Nikendei 131 et al. 2014). However, such a ratio is difficult to achieve in educational institutions. Therefore, 132 from a pragmatic point of view it is important to evaluate whether Peytons's teaching approach 133 can be used with more students per teacher.

134 These inconsistencies should be further investigated through a systematic review. Therefore, the 135 aims of this study were i) to systematically evaluate the effectiveness of Peyton's 4 step teaching 136 approach on the acquisition of procedural skills in health professions education and ii) to 
137 evaluate whether studies with fewer students per teacher (i.e. the student-teacher ratio) showed a

138 larger between group difference than studies with more students per teacher.

139

\section{Materials \& Methods}

141 A protocol of this systematic review was registered in the OSF registries:

142 https://doi.org/10.17605/OSF.IO/5UE7C. To improve clarity of reporting the PRISMA statement

143 was followed (Moher et al. 2011).

\section{Searches}

145 We searched the following electronic databases for eligible studies: Medline, PsycInfo, Embase

146 and Education Resources Information Center (ERIC). The search was performed by KMS. No

147 restrictions regarding recency or publication language were set. The search strategy was prepared

148 using two blocks. The first block consisted of terms relevant for the identification of the

149 population (i.e. students in health professions education). We searched for keywords and mapped

150 the keywords to relevant subject headings. The second block was designed to identify studies

151 using Peyton's teaching approach. Both search blocks were combined using the Boolean

152 operator "and". The search strategy is reported in Appendix 1. In addition, references of included

153 studies were checked for potential eligible studies.

\section{Selection criteria}

155 The following selection criteria were applied.

156 Types of studies to be included

157 Randomised controlled trials were included. If sufficient data was available cross-over studies

158 were eligible as well.

\section{Participants}

160 Only studies reporting on students in health professions education were included. Health

161 professions education was used as an umbrella term for medical and allied health profession

162 education (e.g. physiotherapy or nursing education). We included studies reporting on

163 undergraduate and postgraduate students.

\section{Interventions}

165 Studies needed to investigate Peyton's 4-step approach for inclusion in at least one study arm 166 (i.e. all 4 steps were used together). 


\section{Comparator}

168 Studies needed to have a comparator group. The comparator could be a specific educational

169 intervention (e.g. team-based education or peer teaching), educational practice as usual (e.g. a

170 "see one - do one") or a sham intervention.

\section{Outcomes}

172 The primary outcome for this review was the evaluation of procedural skills. These could be

173 evaluated using a performance metric such as a procedure specific checklist or a global rating

174 scale. To be included studies had to report on this outcome. The secondary outcome was the time

175 needed to perform the procedure. If multiple procedures were trained one procedure was selected

176 for inclusion in order to avoid a unit of analysis issue (i.e. in order to avoid including the same

177 participants twice within a single analysis). Means and standard deviations of continuous

178 outcomes were extracted. If standard deviations were not reported we imputed standard

179 deviations based on standard errors or confidence intervals as suggested in the Cochrane

180 Handbook (Higgins et al. 2019).

\section{Study selection and data extraction}

182 Records were screened by two independent reviewers (RC and KMS). The screening procedure

183 was performed using the Rayyan software (Ouzzani et al. 2016). Disagreements were solved by

184 discussion between RC and KMS. If a referee was needed KG was consulted. One reviewer

185 (KMS) extracted relevant data into an electronic database and a second reviewer (KG) controlled 186 the data.

\section{Risk of bias assessment}

188 The risk of bias was evaluated using the Cochrane risk of bias tool (Higgins et al. 2011). A

189 human reviewer (KMS) evaluated all included studies with respect to these items: sequence

190 generation, allocation concealment, blinding of a) participants and personnel and b) outcome

191 assessors, incomplete outcome data and selective reporting. Evaluations were compared against a

192 machine learning classification of the risk of bias with the application "RobotReviewer"

193 (Marshall et al. 2015). Disagreements were solved by discussion with a third person.

194 Strategy for data synthesis

195 The primary endpoint for evaluating the effectiveness of the comparisons was at the end of the

196 intervention. A secondary analysis was performed using data from the longest available follow

197 up endpoint. 
198 Data analysis

199 The analysis was performed using the statistical software package R (R Core Team 2019). A

200 meta-analysis of pairwise comparisons was performed using the meta package (Schwarzer 2007).

201 A random effects model was used for the analysis and effectiveness was reported using

202 standardized effect sizes (Hedges' g) and corresponding 95\% confidence intervals. The Hartung,

203 Knapp, Sidik, Jonkmann adjustment was applied to achieve robust estimations of the treatment

204 effect (IntHout et al. 2014). Effect sizes were interpreted following Cohen (1992). This means

205 that an effect size of 0.2 was considered as small, 0.5 as medium and 0.8 as large. Statistical

206 heterogeneity was assessed with $\mathrm{I}^{2}$ statistics using the guidelines presented in the Cochrane

207 handbook for systematic reviews of interventions (Higgins \& Green 2011). The following

208 categories were applied: 0-40\% might not be important, 30-60\% moderate heterogeneity, 50-

$20990 \%$ substantial heterogeneity and $75-100 \%$ considerable heterogeneity.

210 A mixed effects meta-regression was performed using the meta package (Schwarzer 2007). We

211 explored the effect of the students per teacher on the estimated effect of the educational

212 interventions. A mixed effects meta-regression was performed using the meta package

213 (Schwarzer 2007). The number of students per teacher during the procedural skills training was

214 used as moderator variable.

215

216 Results

217 Findings of the search

218 The electronic search on the databases Medline, PsycInfo, Embase and ERIC identified 482

219 potential eligible records. In addition, the screening of the abstracts identified 5 further records.

220 After removing 45 duplicates, 442 titles and abstracts were screened. In this phase of the

221 selection process 405 records were excluded. The full-texts of the remaining 37 records were

222 assessed for eligibility and 23 records were excluded with the following reasons: 12 records

223 reported an intervention, which was not eligible for inclusion (Bode et al. 2012; Bube et al. 2017;

224 Craven et al. 2018; Custers et al. 1999; Handley \& Handley 1998; Hill et al. 2010; Holmes et al.

225 1998; Krautter et al. 2015; Liu \& Hunt 2017; Velmahos et al. 2004; Wirth et al. 2018;

226 Yoganathan et al. 2018); 8 records used a study design, which was not eligible for inclusion

227 (Easton et al. 2012; Mishra \& Dornan 2003; Nikendei et al. 2014; Schroder et al. 2017; Skrzypek

228 et al. 2018; Smith et al. 2019; Sopka et al. 2012; Tommaso 2016); 2 records were excluded

229 because of missing data (Archer et al. 2015; Seymour-Walsh et al. 2015) and 1 record did not

230 use the specified primary outcome assessment for procedural skills (Greif et al. 2010). Finally,

23114 studies were included into this systematic review. An overview of the selection process is

232 presented in Fig.1. During the study selection process, 6 conflicts occurred, representing 1.4\% of

233 the total decisions.

234

235 Figure 1. Prisma flow diagram 


\section{Included studies}

238 The 14 included studies in this review were all randomised controlled studies. An overview of 239 included studies and study characteristics is presented Table 1. Most of the included studies were 240 conducted in Germany $(\mathrm{n}=10)$. Four studies with 3 or 4 study arms were included (Gradl-Dietsch 241 et al. 2018; Herrmann-Werner et al. 2013; Münster et al. 2016; Ruesseler et al. 2019). In these

242 cases, study arms investigating Peyton's teaching approach or a standard teaching approach were 243 included. Study arms using an intervention not eligible for inclusion were excluded from this review. For example, Gradl-Dietsch et al. (2018) reported 4 study arms. The study arms peer teaching and peer teaching using Peyton's teaching approach were included. Not included were the study arms team-based learning and video-based learning. All used study arms are presented in Table 1. The included participants in most studies were within medical education. A range from first year medical students to residents in obstetrics and gynaecology was identified. Two studies used participants from nursing education (Lapucci et al. 2018; Orde et al. 2010) and one study was conducted with participants from physiotherapy education (Rossettini et al. 2017). A broad range of trained procedures has been identified. For example, basic surgical skills (Ruesseler et al. 2019), spine mobilisations (Gradl-Dietsch et al. 2016; Rossettini et al. 2017), musculoskeletal ultrasound (Gradl-Dietsch et al. 2019) or cardiopulmonary resuscitation (Jenko et al. 2012) were used as procedures. Several modified versions of Peyton's teaching approaches were used in the experimental groups. All studies with exception of five studies (Gradl-Dietsch et al. 2019; Gradl-Dietsch et al. 2018; Herrmann-Werner et al. 2013; Münster et al. 2016; Ruesseler et al. 2019) used a standard version of Peytons's teaching approach.

The study of Herrmann-Werner et al. (2013) used a best practice skills laboratory, which consisted of structured individual feedback, performance on manikins and Peyton's teaching approach supervised by student tutors. Three studies (Gradl-Dietsch et al. 2019; Gradl-Dietsch et al. 2018; Münster et al. 2016) used peer or student teachers for the teaching events and Ruesseler et al. (2019) used a video 4-step approach. The teaching approach in the control groups was described as traditional Halsted teaching (Balafoutas et al. 2019; Romero et al. 2018), peer teaching or student tutors teaching (GradlDietsch et al. 2019; Gradl-Dietsch et al. 2018; Herrmann-Werner et al. 2013; Münster et al. 2016), 2-stage teaching approach (Jenko et al. 2012), Orde's 2-step method (Lapucci et al. 2018; Orde et al. 2010), standard instructions (Gradl-Dietsch et al. 2016; Krautter et al. 2011), traditional bedside teaching (Lund et al. 2012) or see one, do one (Rossettini et al. 2017; Ruesseler et al. 2019). The time allocated to the teaching of the procedural skills was set equal in most included studies. Four studies (Herrmann-Werner et al. 2013; Krautter et al. 2011; Lund et al. 2012; Rossettini et al. 2017) used this variable as outcome measure. All of them reported that between the groups the same or a similar amount of time was required for teaching. Data to evaluate the following comparisons were available:

- Peyton's teaching approach versus a standard teaching approach (PEY vs ST) 
275

276

277

278

279

280

281

282

283

284

285

286

287

288

289

290

291

292

293

294

295

296

297

298

299

300

301

302

303

304

305

306

307

308

309

310

311

312

- Peyton's teaching approach with peer teaching versus a standard teaching approach with peer teaching (PeerPey vs PeerSt)

- Best practice skills lab with peer teaching versus a standard teaching approach with peer teaching (PeerBpsl vs PeerSt)

- Media supported Peyton's teaching approach versus a standard teaching approach (MPey-St)

- All forms of Peyton's teaching approach versus a standard teaching approach

Table 1. Characteristics of included studies

*if multiple procedures or assessments were used in the primary studies the included procedures and assessments within this systematic review are underlined.

During the controlling of the data set (https://doi.org/10.6084/m9.figshare.12619151) 7 data entries were flagged and double checked. This corresponded to $2.43 \%$ of the data set.

\section{Analysis of effectiveness}

Below the analysis of effectiveness is presented reporting on two outcomes (i.e. performance and time needed to perform the procedure) at two different endpoints (i.e. after acquisition and after a retention period).

\section{Performance - post-acquisition test}

Fourteen studies reporting on 17 samples with a total of 970 participants allocated to Peyton's teaching approach and 935 allocated to a standard teaching approach were included for the analysis of the outcome performance at post-acquisition testing. Four different sub-groups were identified. First, 9 studies compared Peyton's teaching approach against a standard teaching approach (Balafoutas et al. 2019; Gradl-Dietsch et al. 2016; Jenko et al. 2012; Krautter et al. 2011; Lapucci et al. 2018; Lund et al. 2012; Orde et al. 2010; Romero et al. 2018; Rossettini et al. 2017). The analysis showed an effect size of 0.5 SMD ( $95 \%$ CI 0.13 to 0.87 ) in favour of the Peyton group. Heterogeneity was substantial with an $\mathrm{I}^{2}$ of $69 \%$. Three studies compared peer or student tutor Peyton's teaching versus peer standard teaching (Gradl-Dietsch et al. 2019; GradlDietsch et al. 2018; Münster et al. 2016). The effect size was in favour of peer standard teaching with a SMD of $-0.15(95 \%$ CI between -0.23 and - 0.06). Heterogeneity was not important within this comparison ( $\left.\mathrm{I}^{2}: 0 \%\right)$. One study reported on the comparison best practice skills lab (Peyton's teaching approach was part of the intervention) with peer tutors versus standard peer teaching (Herrmann-Werner et al. 2013). A large effect in favour of best practice skills lab training was identified (SMD: $1.38 ; 95 \%$ CI between -0.56 and 3.32). The $\mathrm{I}^{2}$ was $0 \%$ for this analysis. The last subgroup compared a media supported Peyton's teaching approach versus standard teaching (Ruesseler et al. 2019). A small effect was analysed in favour of the Peyton group with a SMD of 0.24 and a $95 \% \mathrm{CI}$ between -0.22 and 0.71 . The overall model showed a small to moderate effect 
313 size in favour of Peyton's teaching approach with an effect size of 0.45 SMD (95\%CI between

3140.15 and 0.75 ). Heterogeneity was substantial with an $\mathrm{I}^{2}$ value of $82 \%$. A prediction interval

315 between -0.6 and 1.5 was analysed (Fig. 2).

316

317 Figure 2. Forest plot performance - Peyton's 4 step versus standard teaching at post-acquisition

318 testing; Pey: Peyton's teaching; St: standard teaching; PeerPey: peer Peyton's teaching; PeerSt:

319 peer standard teaching; PeerBpsl: peer best practice skills lab; MPey: Media supported Peyton

320 NB. Gradl-Dietsch et al. (2018) and Gradl-Dietsch et al. (2016) are presented as two samples

321 because data for women and men are analysed separately (a: woman, b: men). Data from

322 Herrmann-Werner et al. (2013) are presented as two samples (a: participants with a 3 months

323 follow up, b: participants with a 6 months follow up)

324

325

326

327

328

329

330

331

332

333

334

335

336

337

338

339

340

341

342

343

344

\section{Performance - retention test}

Five studies were included for the outcome performance at retention testing. The studies reported a total of 169 participants in the Peyton group and 135 in the standard teaching group (Fig. 3). It was possible to analyse three different subgroups. First, three studies reported on the comparison Peyton versus standard teaching (Gradl-Dietsch et al. 2016; Orde et al. 2010; Rossettini et al. 2017). A small to moderate effect in favour of the Peyton group was identified (SMD: 0.38 ; with a $95 \%$ CI between -0.14 and 0.9 ). Moderate heterogeneity was analysed ( $\mathrm{I}^{2}$ : $52 \%)$. The second subgroup compared peer best practice skills lab teaching with standard peer teaching (Herrmann-Werner et al. 2013). A large effect size was analysed in favour of best practice skills lab training SMD: 2.54 (95\% CI between 1.75 and 3.33). The third subgroup compared Peyton's peer teaching with standard peer teaching. An SMD of -0.11 with a 95\% CI between -0.51 and 0.3 in favour of peer standard teaching was analysed.

The random effects model over all subgroups showed a moderate to large effect size in favour of Peyton's teaching approach at retention testing (SMD: 0.7 with a 95\%CI between -0.09 and 1.49). The heterogeneity of this analysis was large ( $\left.\mathrm{I}^{2}: 90 \%\right)$. The retention period ranged between 1 month (Rossettini et al. 2017) and 6 months (Gradl-Dietsch et al. 2016).

Figure 3. Forest plot performance - Peyton's 4 step versus standard teaching at retention testing; Pey: Peyton's teaching; St: standard teaching; PeerBpsl: peer best practice skills lab; PeerSt: peer standard teaching; PeerPey: peer Peyton's teaching

\section{Time needed for procedure - post-acquisition test}

Six studies with a total of 657 participants in the Peyton group and 655 in the standard teaching group were included in this analysis (Fig. 4). Two different subgroups were identified. One study compared peer Peyton's teaching versus peer standard teaching (Gradl-Dietsch et al. 2019). An effect size of 0.05 SMD ( $95 \%$ CI between -0.07 and 0.18 ) was analysed. The second subgroup compared Peyton's teaching approach with standard teaching. Five studies were included in this 
351

352

353

354

355

356

357

358

359

360

361

362

363

364

365

366

367

368

369

370

371

372

373

374

375

376

377

378

379

380

381

382

383

384

385

386

387

analysis (Krautter et al. 2011; Lund et al. 2012; Orde et al. 2010; Romero et al. 2018; Rossettini et al. 2017). Findings were in favour of Peyton's teaching approach with a large effect size of $1.06 \mathrm{SMD}$ and a $95 \%$ CI between -2.77 and 0.65 . The overall model showed that participants in the Peyton groups needed considerably less time to perform the procedures at post-acquisition testing. A large effect size of -0.8 SMD $(95 \% \mathrm{CI}$ between -2.13 and 0.53$)$ was associated with this finding. The heterogeneity for this analysis was large with an $\mathrm{I}^{2}$ of $92 \%$. The prediction interval was between -3.21 and 1.62 .

Figure 4. Forest plot time needed for procedure - Peyton's 4 step versus standard teaching at post-acquisition testing; PeerPey: peer Peyton's teaching; PeerSt: peer standard teaching; Pey: Peyton's teaching; St: standard teaching

\section{Time needed for procedure - retention test}

For the analysis time needed for the procedure at retention testing two studies were included (Orde et al. 2010; Rossettini et al. 2017). Both studies compared Peyton's 4 step teaching approach with a standard teaching approach. A large effect size of -2.65 SMD $(95 \%$ CI: -7.77 to 2.47) showed that the time needed to perform the procedure was considerable shorter after a training using Peyton's teaching approach. Heterogeneity was large ( $\left.\mathrm{I}^{2}: 98 \%\right)$. The retention period ranged between 1 month (Rossettini et al. 2017) and 2 months (Orde et al. 2010).

\section{Meta-regression student teacher-ratio - performance post-acquisition}

A univariable meta-regression was performed to analyse whether the student-teacher ratio was an independent predictor of performance on post-acquisition tests. All studies from the metaanalysis "performance - post-acquisition test" with exception of the study of Ordre et al. (2010) (i.e. the authors did not report the student-teacher ratio) were included into the meta-regression. The meta-regression showed that the effectiveness of Peyton's teaching approach was higher in studies with fewer of students per teacher (Fig. 5). The overall model explained $58 \%$ of the variability of the effect sizes (p: $0.01, \mathrm{r} 2: 56.86 \%$ ) and the students per teacher variable showed that for one student more per teacher, the effect size was reduced by 0.08 . This association was statistically significant (b1: -0.08 (95\% CI: -0.14 to -0.0232$)$, t: -2.96 , p: 0.01 ).

Figure 5. Scatterplot meta-regression students per teacher as predictor for performance at postacquisition testing

\section{Risk of Bias}

The risk of bias was low for all studies regarding the item random sequence generation with exception of the study of Ruesseler and colleagues (2019), which was classified as unclear. Regarding the allocation concealment most studies were rated as unclear with exception of two studies (Gradl-Dietsch et al. 2019; Jenko et al. 2012). Blinding of participants and personnel was rated as high risk of bias in all studies with exception of the study of Rossettini et al. (2017). 
388 The authors stated that the participants and teachers were blinded to the aims of the study. The

389

390

391

392

393

394

395

396

397

398

399

400

401

402

403

404

405

406

407

408

409

410

411

412

413

414

415

416

417

418

419

420

421

422

423

424

425

426

risk of bias regarding outcome assessment was low. Only two studies were rated as unclear regarding this risk of bias item blinding of outcome assessment (Lapucci et al. 2018; Münster et al. 2016). One study was assessed as having a high risk of bias regarding incomplete outcome assessment because a relatively high number of study discontinuations were reported (Münster et al. 2016). A summary risk of bias plot is presented in Fig. 6. Regarding the agreement of the human reviewer and the machine learning algorithm it was possible to compare 48 risk of bias evaluations. No conflicts occurred in $37(77 \%)$ decisions and $11(23 \%)$ decisions resulted in a conflict.

Figure 6. Summary risk of bias plot

\section{Sensitivity analyses}

Findings from a crossover study of Gradl-Dietsch and co-workers (2019) were integrated into the meta-analysis and the study was treated as parallel group trial. In order to address a potential unit of analysis issue a sensitivity analysis was performed. Because data from paired analyses were not available we adjusted the study data based on a method described by Elbourne et al. (2002). A correlation coefficient derived from the data of Lund et al. (2012) was used to calculate an adjusted standard error.

For the meta-analysis performance at post-acquisition, the standard error of the study decreased from 0.06 to 0.04 . The effect estimate of the analysis peer Peyton versus peer standard teaching remained -0.15 SMD with a slightly changed $95 \%$ CI between -0.22 to -0.08 .

The adjusted standard error had only minimal influence on the meta-regression of the student teacher ratio at post-acquisition. The overall model (p: 0.01, r2: 57.54\%) and the students per teacher variable (b1: -0.08 (95\% CI: --0.14 to -0.0232$)$, t: -2.96 , p: 0.01 ) remained significantly related to the mean effect size.

Within the meta-analysis time needed for the procedure at post-acquisition testing the sensitivity analysis resulted in a slightly smaller standard error of the Gradl-Dietsch et al. (2019) study. Therefore, the effect estimate of the comparison peer Peyton's teaching versus peer standard teaching changed to $0.05 \mathrm{SMD}$ with a $95 \% \mathrm{CI}$ between -0.05 and 0.16 . The effect estimate of the overall model did not change.

\section{Discussion}

This systematic review with meta-analysis and integrated meta-regression set out to evaluate the effectiveness of Peyton's teaching approach compared with a standard teaching approach. The primary finding was that Peyton's teaching approach was more effective than a standard teaching approach on the acquisition of procedural skills at post-acquisition testing. A small to moderate effect size was associated with this finding. However, different subgroups of Peytons's teaching approach were analysed and effectiveness differed between subgroups. Two comparisons

Peer) reviewing PDF | (2020:07:50815:1:1:NEW 28 Aug 2020) 
427 showed findings in favour of Peyton's teaching approach when the procedure was instructed by 428 teachers or faculty members (i.e. Peyton versus standard teaching and media supported Peyton's 429 teaching approach versus a standard teaching approach). Two comparisons used peers to perform 430 the procedural skills training. Peer Peyton versus peer standard teaching showed inconclusive results with a small effect size in favour of peer standard teaching. In contrast the comparison peer best practice skills lab versus peer standard teaching showed a large effect size in favour of peer best practice skills lab. Therefore, it remains unclear whether Peyton's teaching approach is effective when peers are used as tutors for the outcome skill acquisition. The meta-analysis of skill acquisition at retention testing was in favour of Peyton's teaching approach with a moderate to large effect size. Both subgroups were in favour of Peyton's approach. However, the effect size for the experimental group was considerable smaller compared to the findings at post-acquisition testing. The comparison peer best practice skills lab versus peer standard teaching showed a large effect size. Considerable larger than the effect size at post-acquisition testing. However, only one study reported on this comparison and more studies are needed to confirm this finding. Regarding the outcome time needed to perform the procedure the findings indicated that participants needed considerably less time to perform a procedure if Peyton's teaching approach was instructed by teachers or faculty members. One study showed a very large effect (Rossettini et al. 2017). This study showed some educational differences to the other studies in the analysis. For example, participants from physiotherapy education were used and the trained procedure was a cervical spine mobilisation. In addition, relatively few students per teacher participated in the teaching events. The potential influence of the different procedures on the effect estimate should be investigated in future studies. An increased effectiveness of Peyton's teaching approach at retention testing was analysed. This was mainly seen in the time needed for procedure outcome. The possible long-term comprehension advantage of Peyton's teaching approach has been previously discussed by Herrmann-Werner et al. (2013). The authors showed that Peyton's teaching approach had an increased long-term effect on the acquisition of simple and complex skills. This finding is of educational importance because deterioration of procedural skills is likely after several weeks (Bonrath et al. 2012) and Peyton's teaching approach could be a useful educational method to reduce this. The meta-regression with the student-teacher ratio as independent predictor showed that Peyton's teaching approach was more effective in groups with fewer students per teacher. This supports the idea that Peyton's teaching approach was designed for a teaching ratio of 1:1 (Nikendei et al. 2014). The student-teacher ratio of the analysed studies ranged between 13:1 (Münster et al. 2016) and several studies using a 1:1 ratio (Balafoutas et al. 2019; Gradl-Dietsch et al. 2016; Krautter et al. 2011; Romero et al. 2018). In studies where 9 or more students per teacher were used the treatment effect was close to zero. The highest effect sizes were analysed in studies using a student teacher ratio of 3:1 (Herrmann-Werner et al. 2013; Rossettini et al. 2017). This indicates that Peyton's teaching approach should ideally be used in groups with 1 to 
4673 students per teacher. If this is not possible, it could be argued that group sizes with less than 9 468 students per teacher are still in favour of Peyton's teaching approach.

469 Furthermore, it should be reported that Münster et al. (2016) reported a median group size of 13

470 students with a range between 9 and 13 participants and Ruesseler et al. (2019) reported a

471

472

473

474

475

476

477

478

479

480

481

482

483

484

485

486

487

488

489

490

491

492

493

494

495

496

497

498

499

500

501

502

503

504

505 maximum group size of 6 participants per teacher. These summary estimates of the variable were used within the meta-regression, but this might have caused some imprecision. In addition, the variable student-teacher ratio was not reported in the study of Orde et al. (2010) and therefore the study was not included into the meta-regression.

The control intervention in this review was labelled as "standard teaching" approach. However, the educational approaches used within the control arms presented a source of heterogeneity. A broad range of approaches was identified such as: Halsted teaching, 2-stage teaching approach, Orde's 2-step method, standard instructions, traditional bedside teaching or see one - do one. These educational approaches show considerable similarities but are not exactly the same interventions. However, all of the standard teaching approaches have in common that they did not include the third step of Peyton's teaching approach (i.e. guiding the teacher through the procedure), which is assumed to be beneficial for skill acquisition (Gradl-Dietsch et al. 2016; Rossettini et al. 2017). To deal with these differences several subgroup analyses were performed. In addition, the meta-analysis was performed using a random effects model. Within the subgroups the statistical heterogeneity was considerable smaller compared to the overall analyses. The overall analyses showed substantial heterogeneity and should therefore be analysed with caution.

Eligible outcome assessments for this systematic review were assessments of procedural skills, which could be a procedure specific checklist or a global rating scale. However, when studies reported both types of assessments, the checklists were preferred. This was justified on the basis of the suggested best methods for evaluation by the Accreditation Council for Graduate Medical Education (ACGME) (ACGME 2000; Swing 2002). Within the guideline, checklists are recommended as "most desirable" when assessing medical procedures. Rating scales are recommended as "potentially applicable method". Therefore, we preferred data based on procedure specific checklists. However, this is a controversial topic and some authors have reported that global rating scales have additional values and should be used when procedural skills are evaluated (Ma et al. 2012; Regehr et al. 1998).

\section{Limitations}

Several other potential effect modifiers exist, which were not explored in this study because we did not specify these analyses in the study protocol. First, Gradl-Dietsch et al. (2016) reported that gender might be considered as potential moderator variable for the effectiveness of Peyton's teaching approach. Within their study the authors suggested that men might benefit more from Peyton's teaching approach compared to women. This could be explained by the results of Ali et al. (2015). The authors reported in a systematic review that the acquisition of surgical skills differs between men and women. However, it is difficult to investigate the gender variable with a 
506 meta-regression because relatively few studies reported the findings for men and women

507 separately.

508 Second, acquiring simple procedures is different from acquiring complex skills (Wulf \& Shea

509 2002). Therefore, the complexity of the procedural skills might affect the effectiveness of

510 Peyton's teaching approach. However, rating the complexity of the included procedures is

511 challenging as procedures from various domains of health professions education were included.

512 Third, the experience of the teacher teaching the procedural skill and the experience of the

513 students learning the skill might affect the effectiveness of Peyton's teaching approach.

514 Findings from a crossover trial of Gradl-Dietsch and co-workers (2019) were integrated into the

515 meta-analysis. Findings from a paired analysis were not available and therefore we used the

516 reported values and treated the study as a parallel group trial.

517 However, when the results of randomised controlled trials and crossover studies are combined,

518 the results of crossover studies should be based on paired analyses (Elbourne et al. 2002). If

519 findings from unpaired analyses are used the confidence intervals are likely too wide and this

520 might give rise to a unit of analysis issue (Higgins et al. 2019). As a consequence, we performed

521 a sensitivity analysis and adjusted the standard errors using a method described by Elbourne et

522 al. (2002). A correlation coefficient derived from the data of Lund et al. (2012) was used to

523 calculate the adjusted standard errors. Unfortunately, it was only possible to calculate the

524 correlation coefficient using the Lund et al. study. The remaining studies did not provide

525 sufficient data. However, findings remained similar after the sensitivity analysis. The only

526 differences were slightly changed $95 \%$ confidence intervals. We have therefore decided to

527 include the study by Gradl-Dietsch et al. (2019) in the analysis.

528 An additional limitation of this review might be that we did not include studies reporting about

529 the effectiveness of George and Doto's teaching approach (2001). Peyton's and George and

530 Doto's teaching approach are similar regarding their stepwise teaching structure. However, the

531 inclusion of this additional educational intervention would have increased the heterogeneity

532 considerably. In view of the relatively high proportion of analysed heterogeneity within our

533 pairwise analyses, we decided against it. However, in the context of a network meta-analysis

534 future studies could possibly compare these two and other reported teaching approaches for the

535 acquisition of procedural skills.

\section{Implications for research}

537 Several implications for research were identified. First, the effectiveness of Peyton's teaching

538 approach on skill acquisition should be explored in various health professions. The included

539 studies reported on the use of Peyton's teaching approach in medical education. Only three

540 studies were found analysing this approach in other health professions. Further studies are

541 therefore needed to investigate this approach in the field of nursing or physiotherapy. Second, the

542 proposed moderator variables gender, skill complexity and level of experience of teacher and

543 students should be further explored. Third, more evidence is needed regarding the use of peer

544 teachers. Fourth, the high effectiveness of the best practice skills lab training should be explored 
545 in further studies. In addition, future studies should investigate a stabilised learning of motor

546 skills with long-term follow up (during the retention phase). Moreover, there is a need to

547 consider also the assessment of the motor skill acquired in ecological settings (e.g. during

548 internships) suggesting an adequate transfer phase.

\section{Implications for practice}

550 Peyton's teaching approach is effective for the acquisition of procedural skills. The evidence is

551 robust for the field of medical education. One might assume that the acquisition of skills in other

552 health professions could also benefit from Peyton's teaching approach. However, this must be

553 further investigated. When Peyton's teaching approach is used the number of students per

554 teacher should be small (e.g. ranging between 1 and 3 students per teacher) to be more effective

555 than a standard teaching approach. Implications for teachers in different healthcare fields (e.g.

556 nursing, physiotherapy or speech and language therapy education) are less robust. However,

557 some procedures within this review are used across healthcare fields. For example, procedures

558 from manual therapy were used in medical education (Gradl-Dietsch et al. 2016) and in

559 physiotherapy education (Rossettini et al. 2017). Educators teaching these procedural skills in

560 different healthcare fields are encouraged to use Peyton's teaching approach (i.e. within the

561 discussed limitations). In addition, given the broad spectrum of included procedures in this

562 review it seems likely that Peyton's teaching approach also applies to procedures in different

563 healthcare fields, but this needs further investigation.

564

565

\section{Conclusions}

566 Peyton's teaching approach is an effective teaching approach for skill acquisition of procedural

567 skills when faculty members are used as teachers. When peer students or student tutors are used

568 as teachers the effectiveness of Peyton's teaching approach is less clear. Peyton's teaching

569 approach is more effective when small groups with few students per teacher are used.

570 List of abbreviations

571 MPey: Media supported Peyton

572 PeerBpsl: peer best practice skills lab

573 PeerPey: peer Peyton's teaching

574 PeerSt: peer standard teaching

575 Pey: Peyton's teaching

576 St: standard teaching

577

578

\section{Acknowledgements}

579 N.a.

580

581

References 
582

583

584

585

586

587

588

589

590

591

592

593

594

595

596

597

598

599

600

601

602

603

604

605

606

607

608

609

610

611

612

613

614

615

616

617

618

619

620

621

622

623

624
ACGME. 2000. Suggested best methods for evaluation. ACGME/ABMS Joint Initiative Attachment/Toolbox of Assessment Methods (September 2000).

Ali A, Subhi Y, Ringsted C, and Konge L. 2015. Gender differences in the acquisition of surgical skills: a systematic review. Surgical endoscopy 29:3065-3073.

American College of Surgeons. 1997. Advanced Trauma Life Support for Doctors. Chicago, II: American College of Surgeons.

Archer E, Van Hoving DJ, and De Villiers A. 2015. In search of an effective teaching approach for skill acquisition and retention: Teaching manual defibrillation to junior medical students. African Journal of Emergency Medicine 5:54-59.

Balafoutas D, Joukhadar R, Kiesel M, Häusler S, Loeb S, Woeckel A, and Herr D. 2019. The Role of Deconstructive Teaching in the Training of Laparoscopy. JSLS : Journal of the Society of Laparoendoscopic Surgeons 23.

Bode R, Moore D, Clarke D, Beasley A, Foti J, Caputo G, and Kelleher K. 2012. A prospective randomized trial of the effectiveness of lumbar puncture simulation training in pediatric residents. Academic Pediatrics 12:e12-e13.

Bonrath EM, Weber BK, Fritz M, Mees ST, Wolters HH, Senninger N, and Rijcken E. 2012. Laparoscopic simulation training: testing for skill acquisition and retention. Surgery 152:12-20.

Bube S, Konge L, and Hansen RB. 2017. Simulation-based training for flexible cystoscopy-A patient transfer randomized trial. Scandinavian Journal of Urology 51:36.

Cameron JL. 1997. William Stewart Halsted. Our surgical heritage. Annals of surgery 225:445.

Cohen J. 1992. A power primer. Psychological bulletin 112:155.

Craven CL, Cooke M, Rangeley C, Alberti S, and Murphy M. 2018. Developing a pediatric neurosurgical training model. Journal of Neurosurgery Pediatrics 21:329-335.

Custers EJ, Regehr G, McCulloch W, Peniston C, and Reznick R. 1999. The Effects of Modeling on Learning a Simple Surgical Procedure: See One, Do One or See Many, Do One? Advances in Health Sciences Education 4:123-143.

Easton G, Stratford-Martin J, and Atherton H. 2012. An appraisal of the literature on teaching physical examination skills. Education for Primary Care 23:246-254.

Elbourne DR, Altman DG, Higgins JP, Curtin F, Worthington HV, and Vail A. 2002. Meta-analyses involving cross-over trials: methodological issues. International journal of epidemiology 31:140-149.

Gagne RM, Wager WW, Golas KC, Keller JM, and Russell JD. 2005. Principles of instructional design. Performance Improvement 44:44-46.

George JH, and Doto FX. 2001. A simple five-step method for teaching clinical skills. Fam Med 33:577-578.

Gradl-Dietsch G, Hitpas L, Gueorguiev B, Nebelung S, Schrading S, and Knobe M. 2019. Undergraduate Curricular Training in Musculoskeletal Ultrasound by Student Teachers: The Impact of Peyton's Four-Step Approach. Zeitschrift fur Orthopadie \& Unfallchirurgie 157:270-278.

Gradl-Dietsch G, Lübke C, Horst K, Simon M, Modabber A, Sönmez TT, Münker R, Nebelung S, and Knobe M. 2016. Peyton's four-step approach for teaching complex spinal

Peer] reviewing PDF | (2020:07:50815:1:1:NEW 28 Aug 2020) 
625

626

627

628

629

630

631

632

633

634

635

636

637

638

639

640

641

642

643

644

645

646

647

648

649

650

651

652

653

654

655

656

657

658

659

660

661

662

663

664

665

666

667

668 manipulation techniques - a prospective randomized trial. BMC medical education 16:284.

Gradl-Dietsch G, Menon AK, Gürsel A, Götzenich A, Hatam N, Aljalloud A, Schrading S, Hölzl F, and Knobe M. 2018. Basic echocardiography for undergraduate students: a comparison of different peer-teaching approaches. European journal of trauma and emergency surgery: official publication of the European Trauma Society 44:143-152.

Grantcharov TP, and Reznick RK. 2008. Teaching procedural skills. Bmj 336:1129-1131.

Greif R, Egger L, Basciani RM, Lockey A, and Vogt A. 2010. Emergency skill training--a randomized controlled study on the effectiveness of the 4-stage approach compared to traditional clinical teaching. Resuscitation 81:1692-1697.

Halsted WS. 1904. The training of the surgeon. Bull Johns Hop Hosp:267-275. \{Halsted, 1904 \#45\}

Handley JA, and Handley AJ. 1998. Four-step CPR - Improving skill retention. Resuscitation 36:38.

Herrmann-Werner A, Nikendei C, Keifenheim K, Bosse HM, Lund F, Wagner R, Celebi N, Zipfel S, and Weyrich P. 2013. "Best Practice" Skills Lab Training vs. a "see one, do one" Approach in Undergraduate Medical Education: An RCT on Students' Long-Term Ability to Perform Procedural Clinical Skills. PloS one 8.

Higgins JP, Altman DG, Gøtzsche PC, Jüni P, Moher D, Oxman AD, Savović J, Schulz KF, Weeks L, and Sterne JA. 2011. The Cochrane Collaboration's tool for assessing risk of bias in randomised trials. Bmj 343:d5928.

Higgins JP, and Green S. 2011. Cochrane handbook for systematic reviews of interventions: John Wiley \& Sons.

Higgins JP, Thomas J, Chandler J, Cumpston M, Li T, Page MJ, and Welch VA. 2019. Cochrane handbook for systematic reviews of interventions: John Wiley \& Sons.

Hill C, Reardon R, Joing S, Falvey D, and Miner J. 2010. Cricothyrotomy technique using gum elastic bougie is faster than standard technique: A study of emergency medicine residents and medical students in an animal lab. Academic Emergency Medicine 17:666669.

Holmes JF, Panacek EA, Sakles JC, and Brofeldt BT. 1998. Comparison of 2 cricothyrotomy techniques: Standard method versus rapid 4-step technique. Annals of Emergency Medicine 32:442-447.

IntHout J, loannidis JP, and Borm GF. 2014. The Hartung-Knapp-Sidik-Jonkman method for random effects meta-analysis is straightforward and considerably outperforms the standard DerSimonian-Laird method. BMC medical research methodology 14:25.

Issenberg BS, Mcgaghie WC, Petrusa ER, Lee Gordon D, and Scalese RJ. 2005. Features and uses of high-fidelity medical simulations that lead to effective learning: a BEME systematic review. Medical teacher 27:10-28.

Jenko M, Frangež M, and Manohin A. 2012. Four-stage teaching technique and chest compression performance of medical students compared to conventional technique. Croatian medical journal 53:486-495.

Kotsis SV, and Chung KC. 2013. Application of see one, do one, teach one concept in surgical training. Plastic and reconstructive surgery 131:1194.

Krautter M, Dittrich R, Safi A, Krautter J, Maatouk I, Moeltner A, Herzog W, and Nikendei C. 2015. Peyton's four-step approach: differential effects of single instructional steps on

Peer) reviewing PDF | (2020:07:50815:1:1:NEW 28 Aug 2020) 
669

670

671

672

673

674

675

676

677

678

679

680

681

682

683

684

685

686

687

688

689

690

691

692

693

694

695

696

697

698

699

700

701

702

703

704

705

706

707

708

709

710

711 procedural and memory performance - a clarification study. Advances in Medical Education \& Practice 6:399-406.

Krautter M, Weyrich P, Schultz JH, Buss SJ, Maatouk I, Ünger JJ, and Nikendei C. 2011. Effects of peyton's four-step approach on objective performance measures in technical skills training: A controlled trial. Teaching and learning in medicine 23:244-250.

Lapucci G, Bondi B, Rubbi I, Cremonini V, Moretti E, Di Lorenzo R, Magnani D, and Ferri P. 2018. A randomized comparison trial of two and four-step approaches to teaching cardiopulmonary reanimation. Acta Biomedica 89:37-44.

Liu B, and Hunt LM. 2017. A single-blinded experimental study on task-shifting: Assessing the acquisition of new surgical skills between medically qualified and non-medically qualified surgical trainees in a low resource area. Colorectal Disease 19:55.

Lom B. 2012. Classroom activities: simple strategies to incorporate student-centered activities within undergraduate science lectures. Journal of Undergraduate Neuroscience Education 11:A64.

Lund F, Schultz JH, Maatouk I, Krautter M, Möltner A, Werner A, Weyrich P, Jünger J, and Nikendei C. 2012. Effectiveness of IV cannulation skills laboratory training and its transfer into clinical practice: A randomized, controlled trial. PloS one 7.

Ma IW, Zalunardo N, Pachev G, Beran T, Brown M, Hatala R, and McLaughlin K. 2012. Comparing the use of global rating scale with checklists for the assessment of central venous catheterization skills using simulation. Advances in Health Sciences Education 17:457-470.

Marshall IJ, Kuiper J, and Wallace BC. 2015. RobotReviewer: evaluation of a system for automatically assessing bias in clinical trials. Journal of the American Medical Informatics Association 23:193-201.

McLeod PJ, Steinert Y, Trudel J, and Gottesman R. 2001. Seven principles for teaching procedural and technical skills. Academic medicine: journal of the Association of American Medical Colleges 76:1080-1080.

Michels ME, Evans DE, and Blok GA. 2012. What is a clinical skill? Searching for order in chaos through a modified Delphi process. Medical teacher 34:e573-e581.

Mishra B, and Dornan T. 2003. Training junior doctors in complex skills. Medical education 37:672-673.

Moher D, Altman DG, Liberati A, and Tetzlaff J. 2011. PRISMA statement. Epidemiology 22:128.

Münster T, Stosch C, Hindrichs N, Franklin J, and Matthes J. 2016. Peyton's 4-Steps-Approach in comparison: Medium-term effects on learning external chest compression - a pilot study. GMS journal for medical education 33:Doc60.

Ng JY. 2014. Combining Peyton's four-step approach and Gagne's instructional model in teaching slit-lamp examination. Perspectives on medical education 3:480-485.

Nikendei C, Huber J, Stiepak J, Huhn D, Lauter J, Herzog W, Junger J, and Krautter M. 2014. Modification of Peyton's four-step approach for small group teaching - a descriptive study. BMC medical education 14:68.

Oermann MH, Muckler VC, and Morgan B. 2016. Framework for teaching psychomotor and procedural skills in nursing. The Journal of Continuing Education in Nursing 47:278-282.

Orde S, Celenza A, and Pinder M. 2010. A randomised trial comparing a 4-stage to 2-stage teaching technique for laryngeal mask insertion. Resuscitation 81:1687-1691.

Peer] reviewing PDF | (2020:07:50815:1:1:NEW 28 Aug 2020) 
712 Ouzzani M, Hammady H, Fedorowicz Z, and Elmagarmid A. 2016. Rayyan-a web and mobile app

713 for systematic reviews. Systematic reviews 5:210.

714 R Core Team. 2019. R: A language and environment for statistical computing. R Foundation for

$715 \quad$ Statistical Computing. Vienna, Austria.

716 Regehr G, MacRae H, Reznick R, and Szalay D. 1998. Comparing the psychometric properties of

717 checklists and global rating scales for assessing performance on an OSCE-format

$718 \quad$ examination. Academic Medicine 73:993-997.

719 Rohrich RJ. 2006. "See one, do one, teach one": an old adage with a new twist. LWW.

720 Romero P, Günther P, Kowalewski KF, Friedrich M, Schmidt MW, Trent SM, De La Garza JR,

721

722

723

724

725

726

727

728

729

730

731

732

733

734

735

736

737

738

739

740

741

742

743

744

745

746

747

748

749

750

751

752

753

754

755 Müller-Stich BP, and Nickel F. 2018. Halsted's "See One, Do One, and Teach One" versus Peyton's Four-Step Approach: A Randomized Trial for Training of Laparoscopic Suturing and Knot Tying. Journal of Surgical Education 75:510-515.

Rossettini G, Rondoni A, Palese A, Cecchetto S, Vicentini M, Bettale F, Furri L, and Testa M. 2017. Effective teaching of manual skills to physiotherapy students: a randomised clinical trial. Medical education 51:826-838.

Ruesseler M, Tomczak M, Thrun M, Pfau S, Marzi I, and Sterz J. 2019. The Influence of the Instructional Approach on Acquiring Clinical Skills in Surgery: A Comparative Effectiveness Study. Journal of Surgical Education 76:140-149.

Sattelmayer M, Elsig S, Hilfiker R, and Baer G. 2016. A systematic review and meta-analysis of selected motor learning principles in physiotherapy and medical education. BMC medical education 16:15.

Sattelmayer M, Hilfiker R, and Baer G. 2017. A systematic review of assessments for procedural skills in physiotherapy education/Assessment von prozeduralen Fähigkeiten in der physiotherapeutischen Ausbildung: Ein systematischer Review. International Journal of Health Professions 4:53-65.

Schroder H, Henke A, Stieger L, Beckers S, Biermann H, Rossaint R, and Sopka S. 2017. Influence of learning styles on the practical performance after the four-step basic life support training approach - An observational cohort study. PLOS ONE [Electronic Resource] 12:e0178210.

Schunk DH. 2012. Learning theories an educational perspective sixth edition: Pearson.

Schwarzer G. 2007. meta: An R package for meta-analysis. $R$ news 7:40-45.

Seymour-Walsh A, Worley P, Vnuk A, and Grantham H. 2015. Is patient morbidity and mortality improved with a skill teaching strategy embedded in learning theory? Resuscitation 96:85.

Simpson EJ. 1966. The classification of educational objectives, psychomotor domain.

Skrzypek A, Gorecki T, Krawczyk P, Podolec M, Cebula G, Jablonski K, Szeliga M, and Nowakowski M. 2018. Implementation of the modified four-step approach method for teaching echocardiography using the FATE protocol-A pilot study. Echocardiography 35:17051712.

Smith J, Moe D, McClellan J, Sohn V, Long W, and Martin M. 2019. See one, do one, but never teach one? An analysis of resident teaching assist cases under various levels of attending supervision. American Journal of Surgery 217:918-922.

Sopka S, Biermann H, Rossaint R, Knott S, Skorning M, Brokmann JC, Heussen N, and Beckers SK. 2012. Evaluation of a newly developed media-supported 4-step approach for basic life 
756

757

758

759

760

761

762

763

764

765

766

767

768

769

770

771

772

773

774

775

776

777

778

779

support training. Scandinavian journal of trauma, resuscitation and emergency medicine 20:37.

Swing SR. 2002. Assessing the ACGME general competencies: general considerations and assessment methods. Academic Emergency Medicine 9:1278-1288.

Tambi R, Bayoumi R, Lansberg P, and Banerjee Y. 2018. Blending Gagne's Instructional Model with Peyton's Approach to Design an Introductory Bioinformatics Lesson Plan for Medical Students: Proof-of-Concept Study. JMIR medical education 4:e11122.

Tommaso CL. 2016. Learning curves for TAVR: Not quite see one, do one teach one. Catheterization \& Cardiovascular Interventions 87:163-164.

Velmahos GC, Toutouzas KG, Sillin LF, Chan L, Clark RE, Theodorou D, and Maupin F. 2004. Cognitive task analysis for teaching technical skills in an inanimate surgical skills laboratory. American Journal of Surgery 187:114-119.

Walker M, and Peyton J. 1998. Teaching in theatre. Teaching and learning in medical practice Rickmansworth, UK: Manticore Europe Limited:171-180.

Wirth S, William YA, Paolini M, Wirth K, Maxien D, Reiser M, and Fischer MR. 2018. Improvement of Radiological Teaching - Effects of Focusing of Learning Targets and Increased Consideration of Learning Theory Knowledge. RoFo Fortschritte auf dem Gebiet der Rontgenstrahlen und der Bildgebenden Verfahren 190:161-174.

Wulf G, and Shea $\mathrm{CH}$. 2002. Principles derived from the study of simple skills do not generalize to complex skill learning. Psychonomic bulletin \& review 9:185-211.

Yoganathan S, Finch DA, Parkin E, and Pollard J. 2018. 360degree virtual reality video for the acquisition of knot tying skills: A randomised controlled trial. International Journal of Surgery 54:24-27.

Peer] reviewing PDF | (2020:07:50815:1:1:NEW 28 Aug 2020) 
Figure 1

\section{Prisma flow diagram}



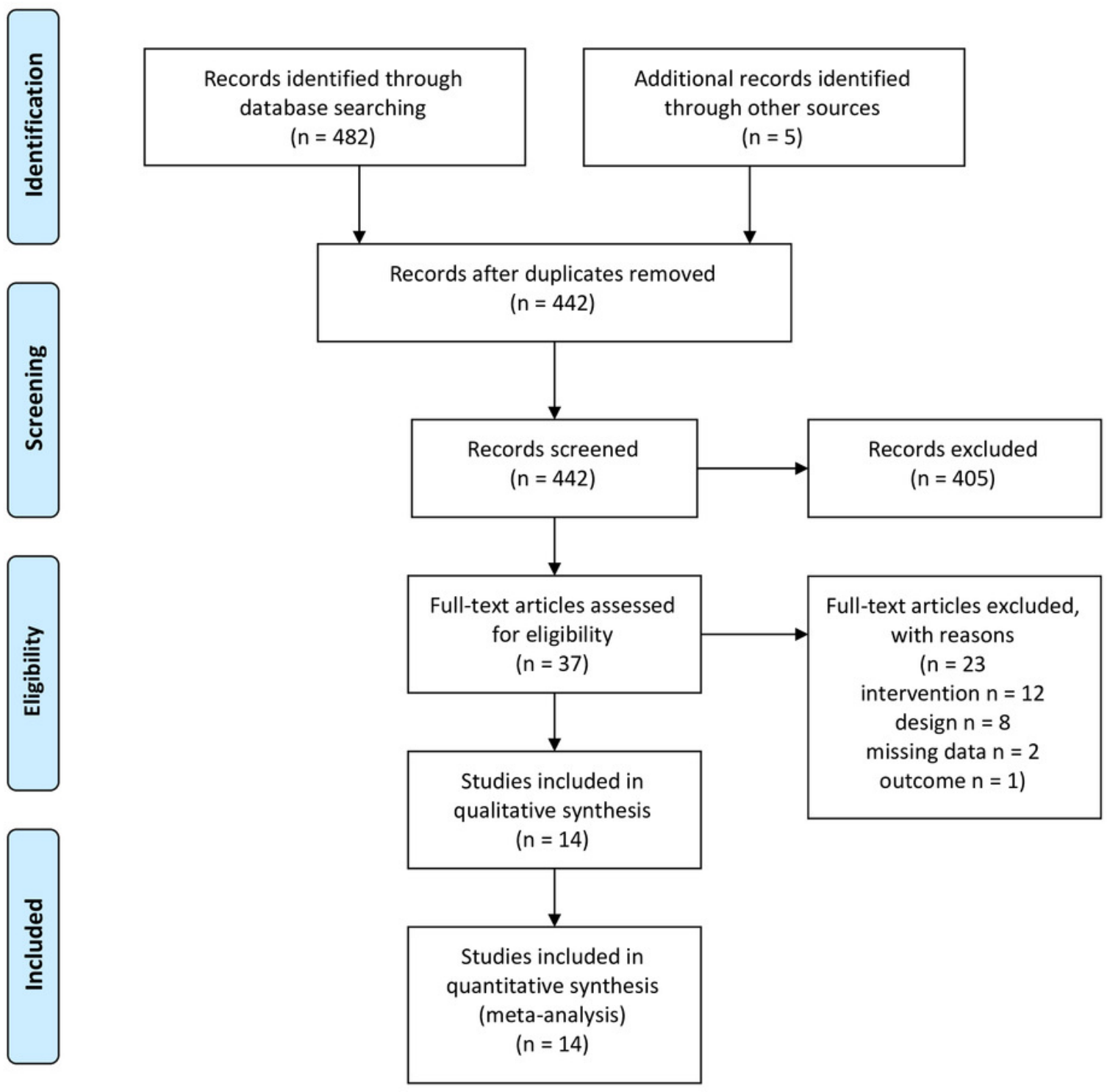


\section{Figure 2}

\section{Forest plot performance - Peyton's 4-step versus standard teaching at post-acquisition testing}

Pey: Peyton's teaching; St: standard teaching; PeerPey: peer Peyton's teaching; PeerSt: peer standard teaching; PeerBpsl: peer best practice skills lab; MPey: Media supported Peyton

NB. Gradl-Dietsch et al. (2018) and Gradl-Dietsch et al. (2016) are presented as two samples because data for women and men are analysed separately (a: woman, b: men). Data from Herrmann-Werner et al. (2013) are presented as two samples (a: participants with a 3 months follow up, b: participants with a 6 months follow up)

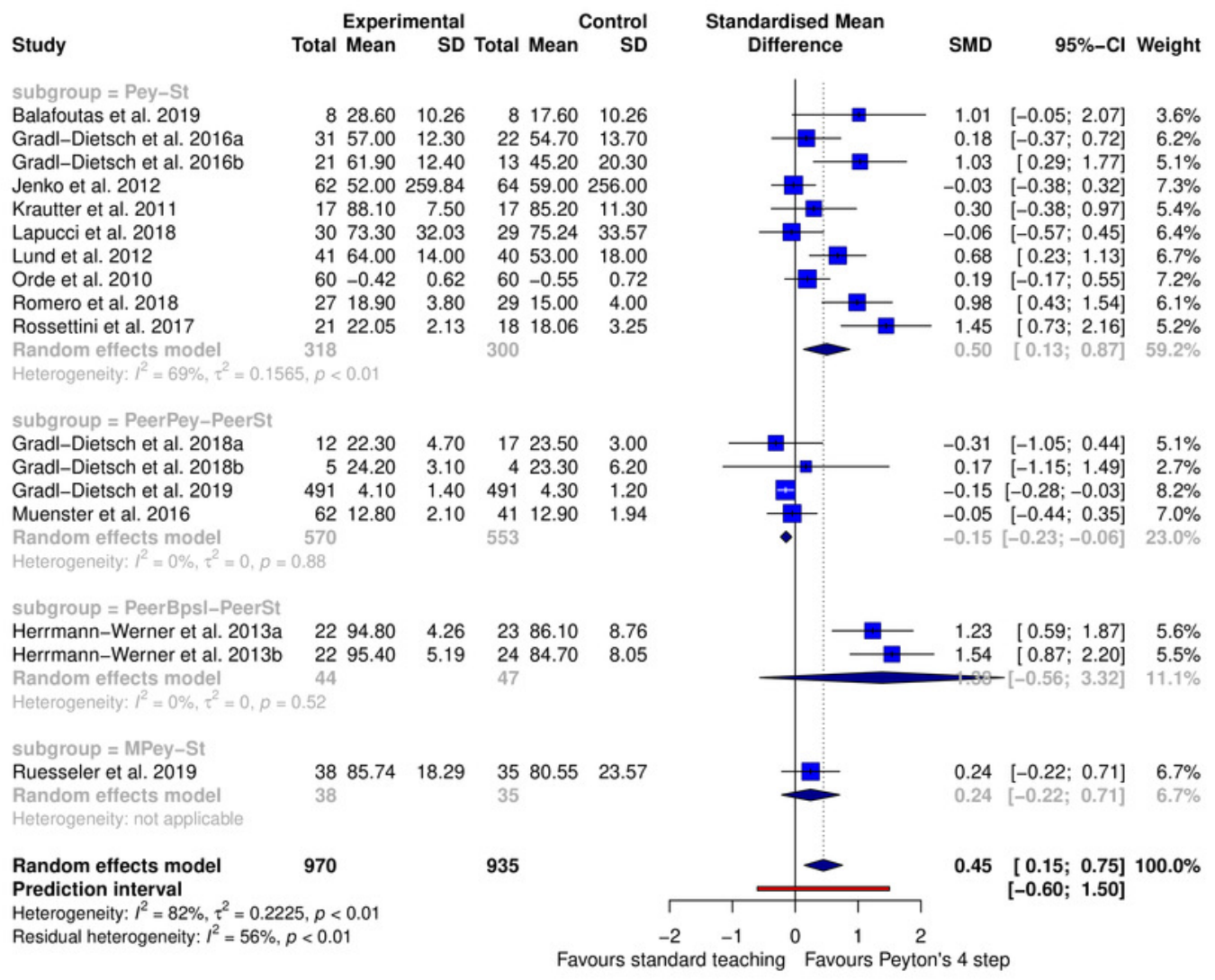


Figure 3

Forest plot performance - Peyton's 4-step versus standard teaching at retention testing

PeerPey: peer Peyton's teaching; PeerSt: peer standard teaching; Pey: Peyton's teaching; St:

standard teaching

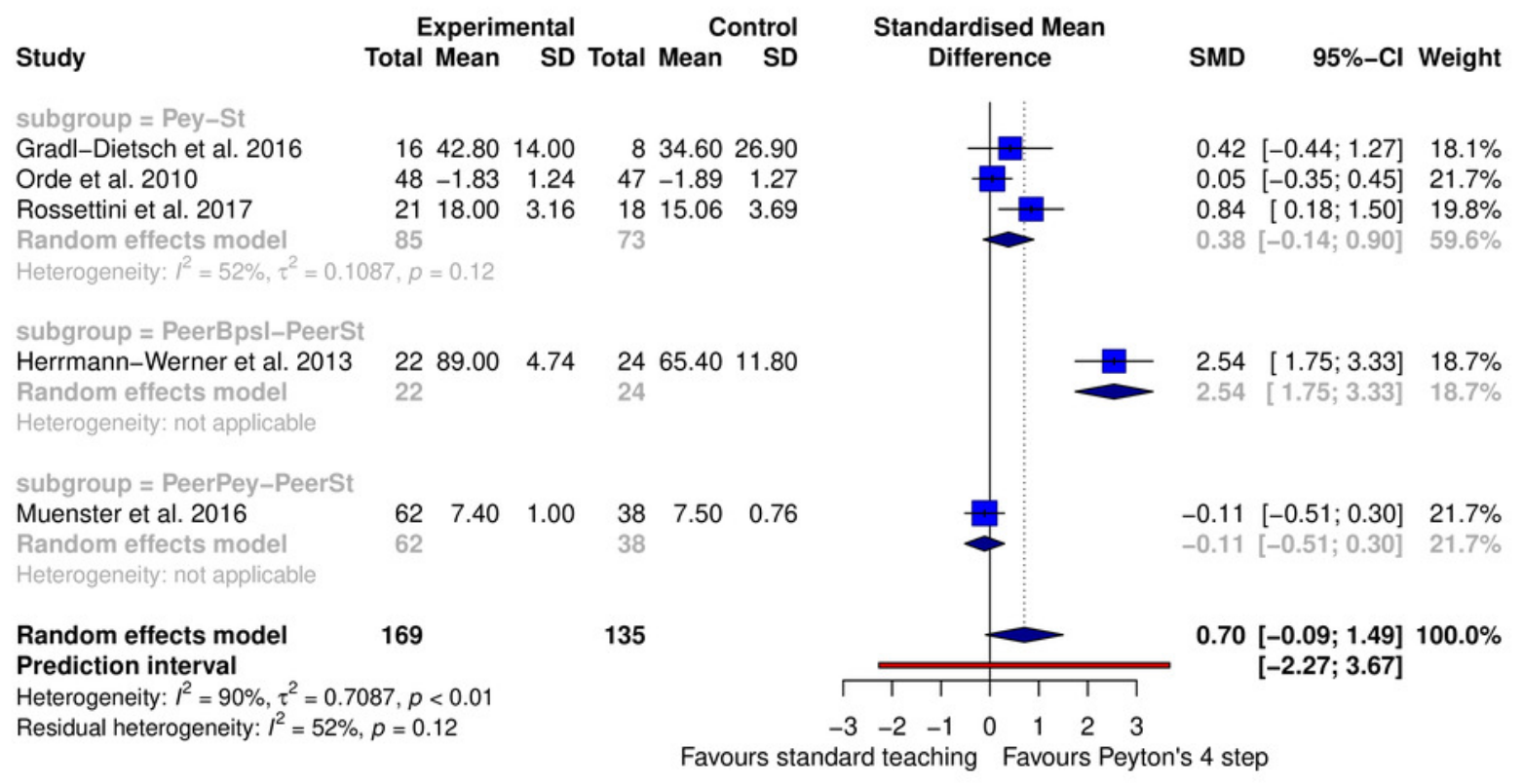


Figure 4

Forest plot time needed for procedure - Peyton's 4-step versus standard teaching at post-acquisition testing;

PeerPey: peer Peyton's teaching; PeerSt: peer standard teaching; Pey: Peyton's teaching; St:

standard teaching

\begin{tabular}{|c|c|c|c|c|c|c|c|c|c|c|}
\hline \multirow{2}{*}{ Study } & \multirow[b]{2}{*}{ Total } & \multicolumn{2}{|c|}{ Experimental } & \multirow[b]{2}{*}{ Total } & \multicolumn{2}{|r|}{ Control } & \multirow{2}{*}{$\begin{array}{l}\text { Standardised Mean } \\
\text { Difference }\end{array}$} & \multirow[b]{2}{*}{ SMD } & \multirow[b]{2}{*}{$95 \%-\mathrm{Cl}$} & \multirow[b]{2}{*}{ Weight } \\
\hline & & Mean & SD & & Mean & SD & & & & \\
\hline \multicolumn{11}{|c|}{ subgroup $=$ PeerPey - PeerSt } \\
\hline Gradl-Dietsch et al. 2019 & 491 & 42.70 & 20.60 & 491 & 41.60 & 19.60 & & 0.05 & {$[-0.07 ; 0.18]$} & $19.5 \%$ \\
\hline $\begin{array}{l}\text { Random effects model } \\
\text { Heterogeneity: not applicable }\end{array}$ & 491 & & & 491 & & & & 0.05 & {$[-0.07 ; 0.18]$} & $19.5 \%$ \\
\hline \multicolumn{11}{|l|}{ subgroup $=$ Pey-St } \\
\hline Krautter et al. 2011 & 17 & 168.00 & 30.00 & 17 & 242.00 & 53.00 & & -1.68 & {$[-2.47 ;-0.88]$} & $14.7 \%$ \\
\hline Lund et al. 2012 & 41 & 595.40 & 188.10 & 40 & 692.70 & 247.80 & & -0.44 & {$[-0.88 ; 0.00]$} & $17.8 \%$ \\
\hline Orde et al. 2010 & 60 & 34.70 & 13.92 & 60 & 39.70 & 19.60 & & -0.29 & {$[-0.65 ; 0.07]$} & $18.4 \%$ \\
\hline Romero et al. 2018 & 27 & 351.00 & 118.00 & 29 & 346.00 & 239.00 & & 0.03 & {$[-0.50 ; 0.55]$} & $17.1 \%$ \\
\hline Rossettini et al. 2017 & 21 & 283.76 & 27.99 & 18 & 387.44 & 30.63 & 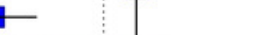 & -3.47 & {$[-4.50 ;-2.45]$} & $12.6 \%$ \\
\hline Random effects model & 166 & & & 164 & & & & -1.06 & {$[-2.77 ; 0.65]$} & $80.5 \%$ \\
\hline \multicolumn{11}{|c|}{ Heterogeneity: $I^{2}=91 \%, \tau^{2}=0.7951, p<0.01$} \\
\hline $\begin{array}{l}\text { Random effects model } \\
\text { Prediction interval }\end{array}$ & 657 & & & 655 & & & & -0.80 & $\begin{array}{l}{[-2.13 ; 0.53]} \\
{[-3.21 ; 1.62]}\end{array}$ & $100.0 \%$ \\
\hline Heterogeneity: $I^{2}=92 \%, \tau^{2}=$ & $=0.488$ & $31, p<$ & & & & & T & & & \\
\hline lesidual heterogeneity: $I^{2}=$ & $1 \%, p$ & $0<0.01$ & & & & -4 & -2 & & & \\
\hline
\end{tabular}

Favours Peyton's 4 step Favours standard teaching 
Figure 5

Scatterplot meta-regression students per teacher as predictor for performance at postacquisition testing

The red line represents the line of equal effectiveness between Peyton's teaching approach and standard teaching. The predicted regression line is plotted in black with corresponding confidence intervals

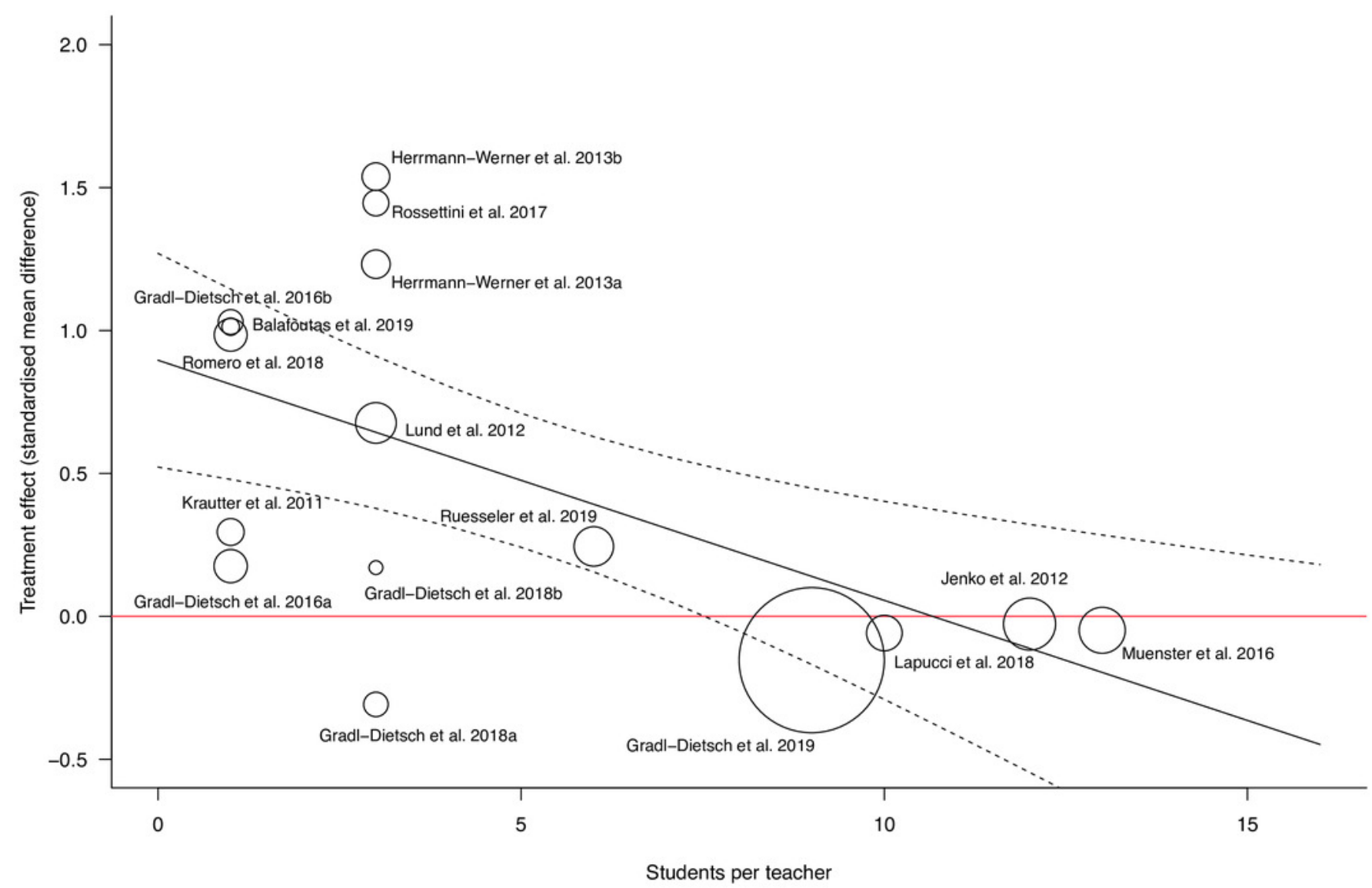


Figure 6

\section{Summary risk of bias plot}

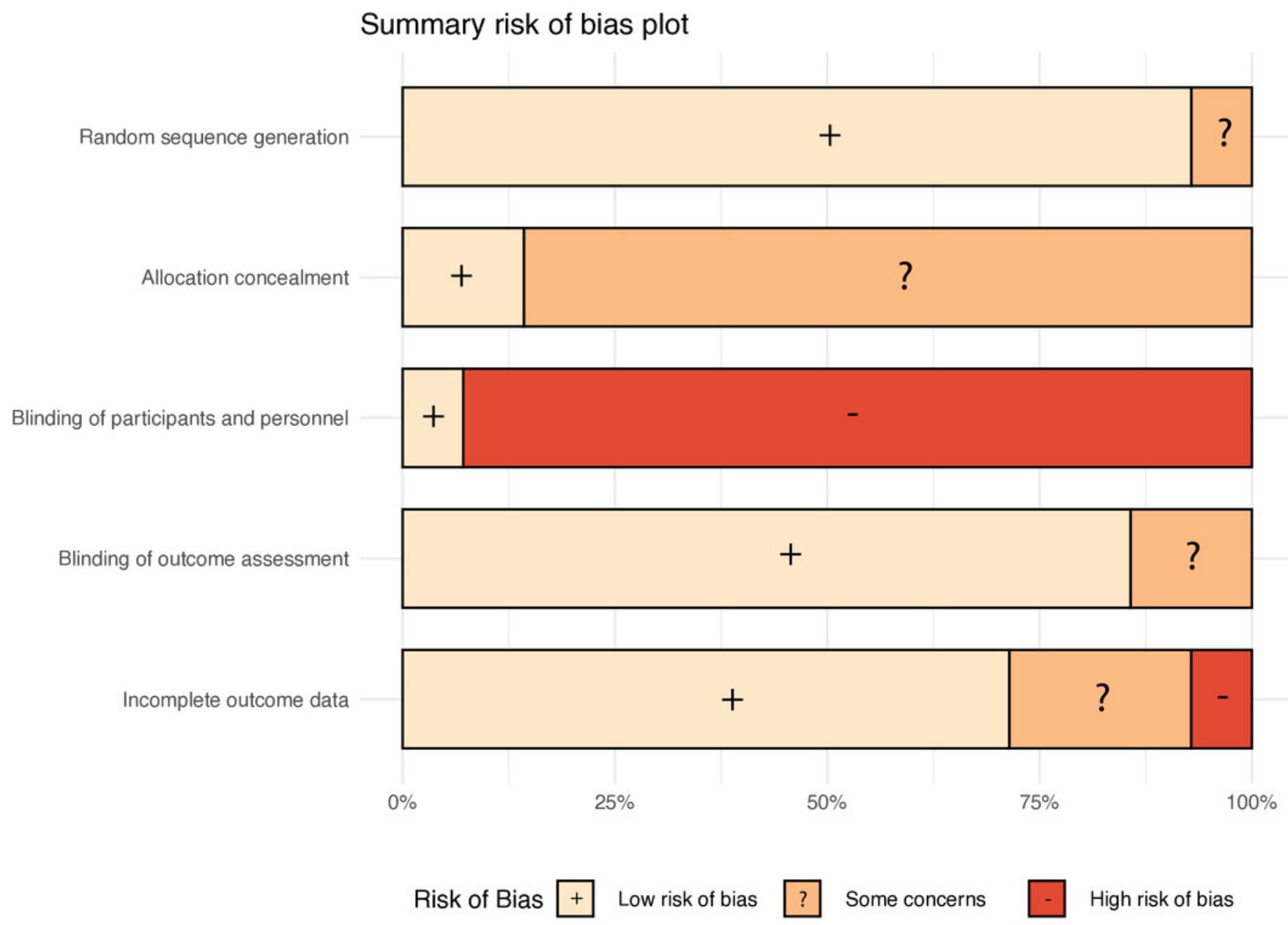


Table $\mathbf{1}$ (on next page)

Characteristics of included studies 
Table 1. Characteristics of included studies

\begin{tabular}{|c|c|c|c|c|c|c|c|c|c|}
\hline Study & $\begin{array}{l}\text { Design/ } \\
\text { Country }\end{array}$ & Participants & $\begin{array}{l}\text { Procedure } \\
\text { trained* }\end{array}$ & $\begin{array}{l}\text { Teaching } \\
\text { approach in } \\
\text { experimental } \\
\text { group }\end{array}$ & $\begin{array}{l}\text { Teaching } \\
\text { approach in } \\
\text { control group }\end{array}$ & $\begin{array}{l}\text { Time } \\
\text { required for } \\
\text { teaching }\end{array}$ & $\begin{array}{l}\text { Student } \\
\text { teacher } \\
\text { ratio }\end{array}$ & $\begin{array}{l}\text { Outcome } \\
\text { measurements* }\end{array}$ & Endpoints \\
\hline $\begin{array}{l}\text { Balafoutas } \\
\text { et al. } \\
(2019)\end{array}$ & $\begin{array}{l}\text { RCT/ } \\
\text { Germany }\end{array}$ & $\begin{array}{l}\mathrm{n}=16 \\
\text { residents in } \\
\text { obstetrics and } \\
\text { gynaecology }\end{array}$ & $\begin{array}{l}\text { Laparoscopic } \\
\text { suturing and knot- } \\
\text { tying training }\end{array}$ & $\begin{array}{l}\text { Deconstruction } \\
\text { of teaching } \\
\text { practical clinical } \\
\text { skills in } 4 \text { steps } \\
\text { (demonstration, } \\
\text { deconstruction, } \\
\text { comprehension, } \\
\text { execution) }\end{array}$ & $\begin{array}{l}\text { Traditional } \\
\text { Halsted } \\
\text { teaching } \\
\text { (demonstration } \\
\text { followed by } \\
\text { execution) }\end{array}$ & $\begin{array}{l}\text { Instructions in } \\
\text { both groups } \\
\text { had a duration } \\
\text { of } 30 \text { min. } \\
\text { Afterwards the } \\
\text { groups } \\
\text { received an } \\
\text { equal amount } \\
\text { of time for } \\
\text { practice }\end{array}$ & $1: 1$ & $\begin{array}{l}\text { Objective } \\
\text { Structured } \\
\text { Assessment of } \\
\text { Technical Skills } \\
\text { tool; number of } \\
\text { correct knots; } \\
\text { mean time } \\
\text { required for knot } \\
\text { tying }\end{array}$ & $\begin{array}{l}\text { Post-test } \\
\text { (after the } \\
\text { training) }\end{array}$ \\
\hline $\begin{array}{l}\text { Gradl- } \\
\text { Dietsch et } \\
\text { al. (2019) }\end{array}$ & $\begin{array}{l}\text { Randomised } \\
\text { cross over } \\
\text { study/ } \\
\text { Germany }\end{array}$ & $\begin{array}{l}\mathrm{n}=491 \\
\text { second year } \\
\text { medical } \\
\text { students }\end{array}$ & $\begin{array}{l}\text { Musculoskeletal } \\
\text { ultrasound } \\
\text { (shoulder and knee } \\
\text { joint) }\end{array}$ & $\begin{array}{l}\text { Peer teaching } \\
\text { according to the } \\
\text { Peyton method } \\
\text { (demonstration, } \\
\text { deconstruction, } \\
\text { comprehension, } \\
\text { execution) }\end{array}$ & $\begin{array}{l}\text { Peer teaching } \\
\text { (demonstration } \\
\text { and execution) }\end{array}$ & $\begin{array}{l}\text { A lesson } \\
\text { lasted } 75 \mathrm{~min} \\
\text { (15 min } \\
\text { theory, } 15 \text { min } \\
\text { demonstration, } \\
45 \text { min } \\
\text { training) in } \\
\text { both groups }\end{array}$ & $9: 1$ & $\begin{array}{l}\text { Objective } \\
\text { structured } \\
\text { practical } \\
\text { examination; } \\
\text { binary } \\
\text { performance } \\
\text { checklist; global } \\
\text { rating scale; time } \\
\text { required }\end{array}$ & $\begin{array}{l}\text { Post-test } 2 \\
\text { weeks after } \\
\text { training }\end{array}$ \\
\hline $\begin{array}{l}\text { Gradl- } \\
\text { Dietsch et }\end{array}$ & $\begin{array}{l}\text { RCT/ } \\
\text { Germany }\end{array}$ & $\begin{array}{l}\mathrm{n}=95 \text { third to } \\
\text { fifth year }\end{array}$ & $\begin{array}{l}\text { Manual therapy } \\
\text { and specific }\end{array}$ & $\begin{array}{l}\text { Instructions } \\
\text { following the }\end{array}$ & $\begin{array}{l}\text { Standard } \\
\text { instructions }\end{array}$ & $\begin{array}{l}\text { Session } \\
\text { duration was }\end{array}$ & $1: 1$ & $\begin{array}{l}\text { Objective } \\
\text { Structured }\end{array}$ & $\begin{array}{l}\text { Post-test (4 } \\
\text { weeks after }\end{array}$ \\
\hline
\end{tabular}




\begin{tabular}{|c|c|c|c|c|c|c|c|c|c|}
\hline al. (2016) & & $\begin{array}{l}\text { medical } \\
\text { students }\end{array}$ & $\begin{array}{l}\text { manipulative and } \\
\text { diagnostic } \\
\text { techniques for the } \\
\text { spine }\end{array}$ & $\begin{array}{l}\text { approach of } \\
\text { Peyton. Steps } 1 \\
\text { and } 2 \text { within } \\
\text { group. Steps } 3 \\
\text { and } 4 \\
\text { individually } \\
\text { (demonstrate, } \\
\text { talk the trainee } \\
\text { through, trainee } \\
\text { talks trainer } \\
\text { through, trainee } \\
\text { does) }\end{array}$ & $\begin{array}{l}\text { (demonstration } \\
\text { and practice) }\end{array}$ & $\begin{array}{l}120 \text { min ( } 30 \\
\text { min theory } \\
\text { and } 60 \text { min } \\
\text { training) in } \\
\text { both groups }\end{array}$ & & $\begin{array}{l}\text { Practical } \\
\text { Examination; } \\
\text { binary } \\
\text { performance } \\
\text { checklist; } \\
\text { Multiple choice } \\
\text { exam (principles } \\
\text { of manual } \\
\text { therapy) }\end{array}$ & $\begin{array}{l}\text { training), } \\
\text { retention test } \\
(6 \text { month) }\end{array}$ \\
\hline $\begin{array}{l}\text { Gradl- } \\
\text { Dietsch et } \\
\text { al. (2018) }\end{array}$ & $\begin{array}{l}\text { 4-arm RCT } \\
\text { (the arms } \\
\text { peer teaching } \\
\text { and Peyton } \\
\text { peer teaching } \\
\text { were } \\
\text { included)/ } \\
\text { Germany }\end{array}$ & $\begin{array}{l}\mathrm{n}=38 \text { second } \\
\text { year medical } \\
\text { students }\end{array}$ & $\begin{array}{l}\text { Echocardiography } \\
\text { including technical } \\
\text { requirements and } \\
\text { patient preparation }\end{array}$ & $\begin{array}{l}\text { Peer teachers } \\
\text { demonstrated } \\
\text { according to } \\
\text { Peyton's } \\
\text { approach } \\
\text { (demonstrate, } \\
\text { talk the trainee } \\
\text { through, trainee } \\
\text { talks trainer } \\
\text { through, trainee } \\
\text { does) }\end{array}$ & $\begin{array}{l}\text { Peer teaching } \\
\text { (peer teachers } \\
\text { demonstrated } \\
\text { the procedure; } \\
\text { students then } \\
\text { practised the } \\
\text { skills on each } \\
\text { other) }\end{array}$ & $\begin{array}{l}\text { Session } \\
\text { duration was } \\
90 \text { min in all } \\
\text { groups }\end{array}$ & $\begin{array}{l}3: 1 \text { for } \\
\text { peer } \\
\text { Peyton; } \\
\text { n.a. for } \\
\text { peer } \\
\text { teaching }\end{array}$ & $\begin{array}{l}\text { Objective } \\
\text { structured } \\
\text { practical } \\
\text { examination; } \\
\text { binary } \\
\text { performance } \\
\text { checklist; global } \\
\text { rating scale; } \\
\text { multiple choice } \\
\text { test }\end{array}$ & $\begin{array}{l}\text { Post-test (2 } \\
\text { weeks after } \\
\text { the training) }\end{array}$ \\
\hline $\begin{array}{l}\text { Herrmann- } \\
\text { Werner et } \\
\text { al. (2013) }\end{array}$ & $\begin{array}{l}\text { arm RCT/ } \\
\text { Germany }\end{array}$ & $\begin{array}{l}\mathrm{n}=94 \\
\text { undergraduate } \\
\text { medical } \\
\text { students }\end{array}$ & $\begin{array}{l}\text { Nasogastral tube } \\
\text { insertion and } \\
\text { intravenous } \\
\text { cannulation }\end{array}$ & $\begin{array}{l}\text { Student tutors } \\
\text { supervised a best } \\
\text { practice skills } \\
\text { laboratory }\end{array}$ & $\begin{array}{l}\text { Student tutors } \\
\text { supervised a } \\
\text { "see one, do } \\
\text { one", teaching }\end{array}$ & $\begin{array}{l}\text { The length of } \\
\text { teaching } \\
\text { sessions did } \\
\text { not }\end{array}$ & $3: 1$ & $\begin{array}{l}\text { Video recordings } \\
\text { of performances } \\
\text { were evaluated } \\
\text { with binary and }\end{array}$ & $\begin{array}{l}\text { Post-test } \\
\text { (immediately } \\
\text { after training) } \\
\text { and retention }\end{array}$ \\
\hline
\end{tabular}




\begin{tabular}{|c|c|c|c|c|c|c|c|c|c|}
\hline & & & & $\begin{array}{l}\text { training } \\
\text { consisting of } \\
\text { structured } \\
\text { individual } \\
\text { feedback, } \\
\text { performance on } \\
\text { manikins and } \\
\text { Peyton's "Four- } \\
\text { Step-Approach } \\
\text { (demonstration, } \\
\text { deconstruction, } \\
\text { comprehension, } \\
\text { performance) }\end{array}$ & & $\begin{array}{l}\text { significantly } \\
\text { differ between } \\
\text { groups }\end{array}$ & & $\begin{array}{l}\text { global checklists; } \\
\text { amount of time } \\
\underline{\text { needed }}\end{array}$ & $\begin{array}{l}\text { test ( } 6 \\
\text { months after } \\
\text { the training) }\end{array}$ \\
\hline $\begin{array}{l}\text { Jenko et } \\
\text { al. (2012) }\end{array}$ & $\begin{array}{l}\text { RCT/ } \\
\text { Slovenia }\end{array}$ & $\begin{array}{l}\mathrm{N}=126 \text { first- } \\
\text { year medical } \\
\text { students }\end{array}$ & $\begin{array}{l}\text { Cardiopulmonary } \\
\text { resuscitation }\end{array}$ & $\begin{array}{l}\text { Peyton's } 4 \text { stage } \\
\text { approach } \\
\text { (demonstration, } \\
\text { deconstruction, } \\
\text { formulation, } \\
\text { performance) }\end{array}$ & $\begin{array}{l}\text { 2-stage } \\
\text { approach } \\
\text { (demonstration } \\
\text { slow speed and } \\
\text { commentary } \\
\text { followed by } \\
\text { performance) }\end{array}$ & $\begin{array}{l}\text { The duration } \\
\text { of the course } \\
\text { was } 4.5 \mathrm{~h} \text { for } \\
\text { both groups }\end{array}$ & 12:1 & $\begin{array}{l}\text { Performance } \\
\text { scores measured } \\
\text { with the manikin: } \\
\underline{\text { compression }} \\
\underline{\text { depth, rate and }} \\
\text { hand placement }\end{array}$ & $\begin{array}{l}\text { Post-test } \\
\text { (immediately } \\
\text { after training) }\end{array}$ \\
\hline $\begin{array}{l}\text { Krautter et } \\
\text { al. (2011) }\end{array}$ & $\begin{array}{l}\mathrm{RCT} / \\
\text { Germany }\end{array}$ & $\begin{array}{l}\mathrm{n}=34 \\
\text { second- and } \\
\text { third-year } \\
\text { medical } \\
\text { students }\end{array}$ & $\begin{array}{l}\text { Gastric-tube } \\
\text { insertion using a } \\
\text { manikin }\end{array}$ & $\begin{array}{l}\text { Peyton's Four- } \\
\text { Step Approach } \\
\text { (demonstrate, } \\
\text { talk the trainee } \\
\text { through, trainee } \\
\text { talks trainer } \\
\text { through, trainee }\end{array}$ & $\begin{array}{l}\text { Standard } \\
\text { instructions: } \\
\text { consisting of } \\
\text { demonstration } \\
\text { with detailed } \\
\text { commentary } \\
\text { and time to ask }\end{array}$ & $\begin{array}{l}\text { No difference } \\
\text { between } \\
\text { length of } \\
\text { instructions } \\
\text { between } \\
\text { groups }\end{array}$ & $1: 1$ & $\begin{array}{l}\text { Acceptance } \\
\text { ratings, length of } \\
\text { time for } \\
\text { instructions, } \\
\text { lengths of time } \\
\text { for first } \\
\text { independent }\end{array}$ & Post-test \\
\hline
\end{tabular}




\begin{tabular}{|c|c|c|c|c|c|c|c|c|c|}
\hline & & & & does) & questions & & & $\begin{array}{l}\text { performance, } \\
\text { video ratings of } \\
\text { performance } \\
\text { including (binary } \\
\text { checklist and } \\
\text { global rating } \\
\text { scale) }\end{array}$ & \\
\hline $\begin{array}{l}\text { Lapucci et } \\
\text { al. (2018) }\end{array}$ & RCT/ Italy & $\begin{array}{l}\mathrm{n}=60 \text { first- } \\
\text { and second- } \\
\text { year nursing } \\
\text { students }\end{array}$ & $\begin{array}{l}\text { Cardio-Pulmonary } \\
\text { Reanimation }\end{array}$ & $\begin{array}{l}\text { Peyton's 4-step } \\
\text { teaching method } \\
\text { (demonstrate, } \\
\text { deconstruction, } \\
\text { comprehension, } \\
\text { execution) }\end{array}$ & $\begin{array}{l}2 \text { step method } \\
\text { described by } \\
\text { Orde (Peyton's } \\
\text { step } 2 \text { and step } \\
\text { 4). }\end{array}$ & $\begin{array}{l}\text { Both groups } \\
\text { received } 15 \\
\text { min of } \\
\text { training }\end{array}$ & $10: 1$ & $\begin{array}{l}\text { Performance } \\
\text { scores: } \\
\text { insufficient chest } \\
\text { compressions, } \\
\text { excessive chest } \\
\text { compressions, } \\
\text { effective chest } \\
\text { compressions and } \\
\text { effective } \\
\text { ventilations }\end{array}$ & $\begin{array}{l}\text { Post-test } \\
\text { (after } \\
\text { training) }\end{array}$ \\
\hline $\begin{array}{l}\text { Lund et al. } \\
\text { (2012) }\end{array}$ & $\begin{array}{l}\text { RCT/ } \\
\text { Germany }\end{array}$ & $\begin{array}{l}\mathrm{n}=84 \text { first- } \\
\text { year medical } \\
\text { students }\end{array}$ & $\begin{array}{l}\text { Intravenous } \\
\text { cannulation on a } \\
\text { part-task-trainer } \\
\text { model in the shape } \\
\text { of a human arm }\end{array}$ & $\begin{array}{l}\text { Training in a } \\
\text { skills lab using } \\
\text { Peyton's } 4 \text { step } \\
\text { approach }\end{array}$ & $\begin{array}{l}\text { Traditional } \\
\text { bedside } \\
\text { teaching based } \\
\text { on "see one, do } \\
\text { one". }\end{array}$ & $\begin{array}{l}\text { Length of } \\
\text { teaching } \\
\text { sessions was } \\
\text { similar } \\
\text { between } \\
\text { groups }\end{array}$ & $3: 1$ & $\begin{array}{l}\text { Video rating with } \\
\text { binary checklist, } \\
\text { global rating } \\
\text { scale, time needed } \\
\text { and number of } \\
\text { attempts and } \\
\text { patient ratings }\end{array}$ & $\begin{array}{l}\text { Post-test in } \\
\text { clinical } \\
\text { setting with } \\
\text { volunteer } \\
\text { students. }\end{array}$ \\
\hline $\begin{array}{l}\text { Münster et } \\
\text { al. (2016) }\end{array}$ & $\begin{array}{l}\text { 3-arm RCT } \\
\text { (the arms }\end{array}$ & $\begin{array}{l}\mathrm{n}=103 \\
\text { second- and }\end{array}$ & $\begin{array}{l}\text { Cardiopulmonary } \\
\text { resuscitation }\end{array}$ & $\begin{array}{l}\text { Student tutors } \\
\text { used Peyton's } 4\end{array}$ & $\begin{array}{l}\text { Student tutors } \\
\text { used a standard }\end{array}$ & $\begin{array}{l}\text { The practical } \\
\text { instructions }\end{array}$ & $\begin{array}{l}\text { median } \\
\text { group }\end{array}$ & $\begin{array}{l}\text { Binary } \\
\text { performance }\end{array}$ & $\begin{array}{l}\text { Post-test (1 } \\
\text { week after }\end{array}$ \\
\hline
\end{tabular}




\begin{tabular}{|c|c|c|c|c|c|c|c|c|c|}
\hline & $\begin{array}{l}\text { Peyton and } \\
\text { standard } \\
\text { teaching } \\
\text { were } \\
\text { included)/ } \\
\text { Germany }\end{array}$ & $\begin{array}{l}\text { third- } \\
\text { semester } \\
\text { medical } \\
\text { students }\end{array}$ & & $\begin{array}{l}\text { step approach } \\
\text { (demonstration, } \\
\text { deconstruction, } \\
\text { modified step } \\
\text { comprehension } \\
\text { for groups, } \\
\text { execution) }\end{array}$ & $\begin{array}{l}\text { teaching } \\
\text { method: } \\
\text { Peyton's step } 2 \\
\text { and } 4 \\
\text { (deconstruction } \\
\text { and } \\
\text { performance } \\
\text { steps) }\end{array}$ & $\begin{array}{l}\text { had a duration } \\
\text { of } 90 \mathrm{~min}\end{array}$ & size 13 & $\begin{array}{l}\text { checklist and } \\
\text { performance data } \\
\text { of the } \\
\text { resuscitation } \\
\text { phantom }\end{array}$ & $\begin{array}{l}\text { training), } \\
\text { retention test } \\
5-6 \text { month } \\
\text { after training) }\end{array}$ \\
\hline $\begin{array}{l}\text { Orde et al. } \\
(2010)\end{array}$ & $\begin{array}{l}\text { RCT/ } \\
\text { Australia }\end{array}$ & $\begin{array}{l}\mathrm{n}=120 \text { final } \\
\text { year medical } \\
\text { students, } \\
\text { nurses and } \\
\text { student nurses }\end{array}$ & $\begin{array}{l}\text { Insertion of a } \\
\text { Laryngeal Mask } \\
\text { Airway on an } \\
\text { airway training } \\
\text { manikin }\end{array}$ & $\begin{array}{l}\text { 4-stage teaching } \\
\text { (demonstration, } \\
\text { deconstruction, } \\
\text { formulation, } \\
\text { performance) }\end{array}$ & $\begin{array}{l}\text { 2-stage teaching } \\
\text { (deconstruction } \\
\text { and } \\
\text { performance } \\
\text { steps) }\end{array}$ & n.a. & n.a. & $\begin{array}{l}\text { Time taken for } \\
\text { insertion, number } \\
\text { of steps correctly } \\
\text { and incorrectly } \\
\text { performed, and } \\
\text { number of steps } \\
\text { omitted }\end{array}$ & $\begin{array}{l}\text { Post-test } \\
\text { (immediately } \\
\text { after } \\
\text { training), } \\
\text { retention test } \\
\text { ( } 2 \text { months } \\
\text { after training) }\end{array}$ \\
\hline $\begin{array}{l}\text { Romero et } \\
\text { al. (2018) }\end{array}$ & $\begin{array}{l}\text { RCT/ } \\
\text { Germany }\end{array}$ & $\begin{array}{l}\mathrm{n}=60 \text { third- } \\
\text { to sixth-year } \\
\text { medical } \\
\text { students }\end{array}$ & $\begin{array}{l}\text { Intracorporal } \\
\text { suturing and knot } \\
\text { tying }\end{array}$ & $\begin{array}{l}\text { Peyton's Four- } \\
\text { Step approach } \\
\text { (demonstration, } \\
\text { deconstruction, } \\
\text { comprehension, } \\
\text { performance) }\end{array}$ & $\begin{array}{l}\text { Halsted } \\
\text { teaching; the } \\
\text { teacher } \\
\text { demonstrated } \\
\text { once afterwards } \\
\text { the students } \\
\text { practiced on } \\
\text { their own }\end{array}$ & $\begin{array}{l}\text { Standardised } \\
\text { training time } \\
\text { of } 60 \mathrm{~min} \text { in } \\
\text { both groups }\end{array}$ & $1: 1$ & $\begin{array}{l}\text { Objective } \\
\text { Structured } \\
\text { Assessment of } \\
\text { Technical Skills } \\
\text { (OSATS) with } \\
\text { checklist and } \\
\text { global rating } \\
\text { scale, } \\
\underline{\text { Performance }} \\
\underline{\text { score, procedural }} \\
\text { implementation, } \\
\text { knot quality, task }\end{array}$ & $\begin{array}{l}\text { Performance } \\
\text { of last suture } \\
\text { (practice } \\
\text { trial) was } \\
\text { assessed }\end{array}$ \\
\hline
\end{tabular}




\begin{tabular}{|c|c|c|c|c|c|c|c|c|c|}
\hline & & & & & & & & $\begin{array}{l}\text { time, and suture } \\
\text { placement } \\
\text { accuracy }\end{array}$ & \\
\hline $\begin{array}{l}\text { Rossettini } \\
\text { et al. } \\
(2017)\end{array}$ & RCT/ Italy & $\begin{array}{l}\mathrm{n}=39 \text { third- } \\
\text { year } \\
\text { undergraduate } \\
\text { physiotherapy } \\
\text { students }\end{array}$ & $\begin{array}{l}\text { Cervical C1-C2 } \\
\text { spine mobilisation }\end{array}$ & $\begin{array}{l}\text { Teaching using } \\
\text { Peyton's four- } \\
\text { step approach } \\
\text { (demonstration, } \\
\text { deconstruction, } \\
\text { comprehension, } \\
\text { performance) }\end{array}$ & $\begin{array}{l}\text { "See one, do } \\
\text { one" approach } \\
\text { as reported by } \\
\text { Herrmann- } \\
\text { Werner et al. } \\
(2013)\end{array}$ & $\begin{array}{l}\text { Time required } \\
\text { for teaching } \\
\text { did not } \\
\text { significantly } \\
\text { differ between } \\
\text { groups. }\end{array}$ & $3: 1$ & $\begin{array}{l}\text { Performance } \\
\text { checklist, time to } \\
\text { teach; time to } \\
\text { perform and } \\
\text { student } \\
\text { satisfaction }\end{array}$ & $\begin{array}{l}\text { Post-test } \\
\text { (after } \\
\text { training), } \\
\text { retention tests } \\
\text { (1 week and } \\
1 \text { month after } \\
\text { training) }\end{array}$ \\
\hline $\begin{array}{l}\text { Ruesseler } \\
\text { et al. } \\
\text { (2019) }\end{array}$ & $\begin{array}{l}\text { Randomised } \\
\text { controlled } \\
\text { cohort study } \\
\text { with 4-arms } \\
\text { (the arms } \\
\text { "video 4-step } \\
\text { approach" } \\
\text { and "See } \\
\text { One - Do } \\
\text { One”) were } \\
\text { included)/ } \\
\text { Germany }\end{array}$ & $\begin{array}{l}\mathrm{n}=73 \text { fourth- } \\
\text { year medical } \\
\text { students }\end{array}$ & $\begin{array}{l}\text { Six procedures } \\
\text { including three } \\
\text { basic surgical } \\
\text { skills (replacement } \\
\text { of a complex } \\
\text { wound dressing, } \\
\text { sterile covering, } \\
\text { and performance } \\
\text { of a suture) }\end{array}$ & $\begin{array}{l}\text { Video 4-step } \\
\text { approach: video } \\
\text { supported step } 1 \\
\text { and 2, the steps } 3 \\
\text { and } 4 \text { were } \\
\text { performed as } \\
\text { reported by } \\
\text { Peyton }\end{array}$ & $\begin{array}{l}\text { "See one, do } \\
\text { one", a trainer } \\
\text { demonstrated } \\
\text { the skill and } \\
\text { explained. } \\
\text { Followed by } \\
\text { practice under } \\
\text { supervision }\end{array}$ & $\begin{array}{l}\text { Teaching units } \\
\text { had equal } \\
\text { duration } \\
\text { between } \\
\text { groups (day1: } \\
90 \text { min per } \\
\text { unit; day 2-5: } \\
210 \text { min per } \\
\text { unit) }\end{array}$ & $\max .6: 1$ & $\begin{array}{l}\text { OSCE with } 6 \\
\text { stations, } \\
\text { performance was } \\
\text { rated on trinary } \\
\text { checklist }\end{array}$ & $\begin{array}{l}\text { Post-test } \\
\text { (during } \\
\text { training } \\
\text { week) }\end{array}$ \\
\hline
\end{tabular}

$4 \quad *$ if multiple procedures or assessments were used in the primary studies the included procedures and assessments within this 5 systematics review are underlined. 